\title{
Parental Support and Pressure in Sports and Children's Anger, Sadness, and Worry Regulation
}

Cara A. Palmer

West Virginia University

Follow this and additional works at: https://researchrepository.wvu.edu/etd

\section{Recommended Citation}

Palmer, Cara A., "Parental Support and Pressure in Sports and Children's Anger, Sadness, and Worry Regulation" (2011). Graduate Theses, Dissertations, and Problem Reports. 3344.

https://researchrepository.wvu.edu/etd/3344

This Thesis is protected by copyright and/or related rights. It has been brought to you by the The Research Repository @ WVU with permission from the rights-holder(s). You are free to use this Thesis in any way that is permitted by the copyright and related rights legislation that applies to your use. For other uses you must obtain permission from the rights-holder(s) directly, unless additional rights are indicated by a Creative Commons license in the record and/ or on the work itself. This Thesis has been accepted for inclusion in WVU Graduate Theses, Dissertations, and Problem Reports collection by an authorized administrator of The Research Repository @ WVU. For more information, please contact researchrepository@mail.wvu.edu. 
Parental Support and Pressure in Sports and Children’s Anger, Sadness, and Worry Regulation

Cara A. Palmer, B.A.

\begin{abstract}
Thesis submitted to the Eberly College of Arts and Sciences at West Virginia University in partial fulfillment of the requirements for the degree of Master of Science in Psychology
\end{abstract}

\begin{abstract}
Amy Gentzler, Ph.D., Chair Aaron Metzger, Ph.D.

Elisa Krackow, Ph.D.

Department of Psychology Morgantown, West Virginia 2011
\end{abstract}

Keywords: emotion regulation, coping, parent-child, support, pressure, sports 


\section{ABSTRACT \\ Parental Support and Pressure in Sports and Children's Anger, Sadness, and Worry Regulation}

Cara A. Palmer

Despite large amounts of child sport participation, research suggests that this activity is not always associated with positive outcomes for youth. This study examined factors that might contribute to discrepant findings associated with youth sports participation. Specifically, parental pressure and support in competitive soccer families and its relation to their children's general emotion regulation were examined. Participants were 91 parent-child dyads (49 males, 42 female, 67 moms, 23 dads) with children between the ages of 8-12 years $(M=10.24, S D=1.19)$. Children completed several self-report measures on their parent's pressure and support behaviors in general and in soccer, as well as on their own regulation of anger, sadness, and worry. More parental pressure in soccer was marginally related to more sadness dysregulation in children, although this relationship was no longer significant after accounting for general parenting

pressure. Results indicated that more support in soccer was related to more dysregulation of worry. However, this relationship only emerged after including general support in the model. Additionally, more pressure in soccer was marginally related to less coping with worry after controlling for general parenting behaviors. A significant interaction indicated that more pressure was related to less coping with worry at low levels of support, whereas more pressure was associated with more coping with worry at high levels of support. However, these results should be interpreted with caution due to nonsignificant simple slopes. Implications for parenting in sports and the socialization of emotions within specific domains are discussed. 


\section{TABLE OF CONTENTS}

I. Introduction (pp. 1-3)

a. Positive and Negative Associations with Sports Participation (pp. 3-5)

b. Emotion Regulation and Sports (pp. 5-6)

c. Parental Influences on Emotion Regulation (pp. 7-8)

d. Parental Pressure and Support in Sports (pp. 8-11)

II. Overview of Present Study (pp. 11-13)

III. Method

a. Participants (pp. 13-14)

b. Procedure (pp. 14)

c. Measures (pp. 14-18)

IV. Results

a. Data Cleaning and Preliminary Analyses (pp. 18-20)

b. Support and Pressure in Soccer Predicting Children's Emotion Regulation (pp. 20-22)

V. Discussion (pp. 22-30)

a. Limitations (pp. 30-34)

b. Implications and Future Directions (pp. 34-36)

VI. References (pp. 37-49)

VII. Table 1: Means, Standard Deviations, and Bivariate Correlations for Support, Pressure, and Emotion Regulation (pp. 50)

VIII. Table 2: Perceived Soccer-Related Parent Support and Pressure Predicting Children’s Anger Regulation (pp. 51) 
IX. Table 3: Perceived Soccer-Related Parent Support and Pressure Predicting Children’s Sadness Regulation (pp. 52)

X. Table 4: Perceived Soccer-Related Parent Support and Pressure Predicting Children’s Worry Regulation (pp. 53)

XI. Figure 1: Interaction between Pressure and Support Predicting Children's Coping with Worry (pp. 54)

XII. Appendices (pp. 55-64) 
Many youth today engage in a variety of activities through their school, church, various clubs, or the community. Among these activities, an estimated 40 to 50 million youth choose to play sports (Ewing \& Seefeldt, 2002). The National Federation of State High School Associations (NFHS, 2009) has reported a continually increasing number of students participating in sports over the past 20 years. Research has highlighted associations between some positive outcomes and sports participation, but a substantial number of studies also suggest a relationship between youth sports and negative outcomes. Due to its achievement-based focus, youth sports can serve as a context for excessive stress due to various factors, such as failure, peer rejection, inappropriate adult behavior, anxiety, and conflict (Fraser-Thomas \& Cote, 2009; Hansen, Larson, \& Dworkin, 2003; Smoll \& Smith, 1996). Also, some research has highlighted a disproportionate number of negative experiences in sports when compared to experiences in other extracurricular activities, such as faith-based, academic, community, and performing arts activities (Dworkin \& Larson, 2006; Hansen et al., 2003). The prevalence of stress-related factors within sports may be leading to this discrepancy in the research and the positive and negative factors that have been associated with sports participation.

Contextual factors, such as parenting behaviors, may influence the child's perception of sports-related stressors and the child’s affective experience within the sport (Anderson \& Anderson, 2000) and may have a moderating influence on child outcomes associated with sports participation. Some specific parenting behaviors that may be influencing children's experiences and perceptions are parental pressure and support. Due to the high rate of negative experiences and stress that children may be faced with when competing in sports, parents may exert an influence on their child by either helping them ameliorate the stress by providing unconditional support, or they can become an additional stressor by intentionally or unintentionally placing 
pressure on their child to succeed (Fredricks \& Eccles, 2008). Children may also look to parents’ behaviors to determine appropriate and inappropriate ways to handle stressful situations (Fredricks \& Eccles, 2008). These support and pressure behaviors may be impacting the stressful experiences that children are encountering within sports, which in turn could be contributing to the prevalence of both positive and negative sports-related outcomes (Duda \& Ntoumanis, 2005; Petitpas, Cornelius, Van Raalte \& Jones, 2005; Shields \& Bredemeier, 1995).

Research on parental influences in organized youth sports have found that support and pressure are related to levels of child sport enjoyment, self-esteem, and sport-related stress (Anderson, Funk, Elliot, \& Smith, 2003; Gould, Eklund, Petlichkoff, Peterson, \& Bump, 1991; Larson, Hansen, \& Moneta, 2006; Leff \& Hoyle, 1995; Scanlan \& Lewthwaite, 1984), and several studies have found an association between parental support and coping in sports (Lafferty \& Dorrell, 2006; VanYperen, 1995). However, very little research has examined the influence of both parental support and pressure in sports on their child's ability to handle non-sport stressors, such as general coping or emotion regulation abilities.

Research on emotion socialization has found that general parenting behaviors play an important role in their child’s development of emotion regulation abilities (Eisenberg, Cumberland, \& Spinrad, 1998; Morris, Silk, Steinberg, Myers, \& Robinson, 2007; Skinner \& Zimmer-Gembeck, 2007). However, there is very little research that has examined parenting behaviors in specific contexts, such as sports participation. It is possible that parents' behaviors may differ in domains that hold great importance to the child, such as their sports participation, and may impact children's development beyond the impact of general parenting behaviors.

This study will attempt to fill in gaps in the current research about potential causes of the variety of positive and negative outcomes that have been associated with sports by examining 
general and sports-specific parental pressure and support. Additionally, this study will look at parenting behaviors within a specific domain and how this relates to general child outcomes. Specifically, this study will investigate the relationship between support and pressure in soccer and children's emotion regulation abilities. Due to the high prevalence and increasing rate of organized youth sports in the United States (Ewing \& Seefeldt, 2002; NFHS, 2009), it is important to better understand the ways in which this extracurricular activity can be a positive resource for children to grow and learn.

\section{Positive and Negative Associations with Sports Participation}

Sports involvement may be a source of positive development for some children, even beyond the positive influence that extracurricular activities may have on youth development as a whole. Studies have found that participation in youth sports is associated with less school dropout (Mahoney \& Cairns, 1997; McNeal, 1995), better academic and occupational outcomes (Barber, Eccles, \& Stone, 2001; Eccles \& Barber, 1999; Gore, Farrell, \& Gordon, 2001), lower levels of social isolation (Barber et al., 2001), less depressed mood for females (Gore et al., 2001), less marijuana use (Barber et al., 2001), and the development of more initiative (Larson et al., 2006), even when compared to other extracurricular activities.

However, despite these research findings on positive outcomes, there are a large number of studies that have found that sports are associated with negative outcomes, and that there are a disproportionate number of negative and stressful experiences in sports when compared to faithbased, academic, community, and performing arts activities (Dworkin \& Larson, 2006; Hansen et al., 2003; Larson et al., 2006). For example, when compared to youth in other activities, those involved in sports have been shown to have more internalizing symptoms and more deviant behaviors, such as cheating on tests, stealing, lying, physical fights, and substance use (Bartko \& 
Eccles, 2003; Eccles \& Barber, 1999; Fauth, Roth, \& Brooks-Gunn, 2007; Gardner, Roth, \& Brooks-Gunn, 2009), poorer levels of adjustment (Darling, Caldwell, \& Smith, 2005), and more aggressive behaviors (Burton \& Marshall, 2005). Other studies have found that sports can be a context for stress, anxiety, anger, negative self-perceptions, and depression (Beedie, Terry, \& Lane, 2000; Burton, 1998; Fraser-Thomas \& Cote, 2009; Hansen, et al., 2003; Smoll \& Smith, 1996). Playing sports is also related to less identity achievement when compared to those who participate in other extracurricular activities (Larson et al., 2006), and in one study it was related to less development of initiative (Hansen et al., 2003). One recent, longitudinal study followed a group of male adolescent hockey players and found that the majority of players experienced decreasing trajectories of positive affect over the course of a season with either unstable levels or a general decline in positive affect over time, and a portion of the participants also experienced increasing trajectories of negative affect (Gaudreau, Amiot, \& Vallerand, 2009).

The causes for these negative outcomes found in the literature are not quite clear. However, youth sports have become "professionalized," with an excessive focus on success rather than on enjoyment and social and emotional development (Gould \& Carson, 2004) and it is possible that this orientation towards achievement and competition is leading to these negative outcomes for children playing sports (Scanlan \& Lewthwaite, 1984; Scanlan, Babkes, \& Scanlan, 2005; Shields \& Bredemeier, 1995). As previously mentioned, research has found that youth report more negative experiences and stress in sports when compared to other activities (Dworkin \& Larson, 2006; Hansen et al., 2003; Larson et al., 2006) and playing organized team sports exposes children to negative peer interactions, exclusion, and inappropriate behaviors by coaches (Hansen et al., 2003; Larson et al., 2006; Smith, Smith, \& Smoll, 1985). In addition, youth are more emotionally involved and invested in sports when compared with other activities 
(Vallerand et al., 2003), which may make them more vulnerable to the ups and downs that may come from their sport participation (Blanchard, Perreault, \& Vallerand, 1998; Brewer, 1993;

Gaudreau et al., 2009; Jones, Glintmeyer, \& McKenzie, 2005). By further examining contextual influences in children's sports participation, such as parenting behaviors, we can find ways to minimize the negative influence of potentially stressful events on development and facilitate children's capitalization on the positive learning opportunities that sports can offer.

\section{Emotion Regulation and Sports}

Emotion regulation has been defined as the voluntary or automatic change to the intensity, duration, or expression of an emotion (Cole, Martin, \& Dennis, 2004; Thompson, 1994). Adaptive emotion regulation is related to more socially appropriate behaviors (Denham et al., 2003; Eisenberg, Spinrad, \& Morris, 2002; Halberstadt, Denham, \& Dunsmore, 2001) and overall adaptive development (Cole et al., 1994). This ability to regulate one’s emotions and respond in socially appropriate ways is one component that facilitates the child's ability to respond to stress (Gross, 1999), and those who have difficulty regulating their emotions may be more likely to have emotional and behavioral problems (Cicchetti, Ackerman, \& Izard, 1995; Eisenberg, Cumberland, et al., 2001; Frick \& Morris, 2004; Silk, Steinberg, \& Morris, 2003).

Due to the number of negative experiences in sports (Dworkin \& Larson, 2006; Hansen et al., 2003), children participating in sports may be exposed to a variety of stressors that can provide valuable learning opportunities for emotion regulation. Children may learn adaptive strategies to handle this sports-related stress and transfer these emotion regulation skills to daily, non-sports related stressors (Larson, 2000; Ryan \& Deci, 2000; Scanlan, 2002). Focus groups with adolescents have found that activity participation in general is ripe with opportunities to learn various emotion regulation skills, such as learning to control emotions like anger and 
anxiety, not allowing these emotions to influence attention and performance, and using positive emotions constructively (Dworkin, Larson, \& Hansen, 2003). This group of researchers also found that sports participation in particular was conducive to more emotional development when compared to community, academic, performing arts, and faith/service based activities (Hansen et al., 2003). However, these studies only looked at self-identified learning experiences, and did not measure any actual learning that took place or current emotion regulation abilities among the participants. Other studies have also suggested that participation in sports may have the potential to lead to more emotional awareness and emotion regulation (Danish, Taylor, \& Fazio, 2003; Scanlan et al., 2005) and that some youth may be able to actively cope with stressful sports experiences by utilizing emotion-focused or problem-focused coping skills (Dworkin \& Larson, 2006). However, little research has examined youth's sport experiences and how these specific experiences may relate to overall emotional awareness and regulation.

Despite these opportunities for positive emotional learning, sports are still related to negative emotional outcomes, such as anxiety, depression, and anger (Beedie et al., 2000; Burton, 1998). Some youth have reported having a difficult time regulating negative emotions from sports and preventing them from spilling over into other aspects of their life (Dworkin \& Larson, 2006) and some athletes are less likely to employ adaptive coping strategies in response to sports-related stressors than other athletes (Eubank \& Collins, 2000; Gaudreau \& Blondin, 2004; Grove \& Heard, 1997). However, predictors of why some children may learn how to handle negative emotions adaptively through sports and why others may learn more maladaptive strategies has yet to be explored in depth. This study will attempt to examine both parental support and pressure in soccer as contextual factors that may influence children's emotion regulation. 


\section{Parental Influences on Emotion Regulation}

Research has shown that parents may influence the development and socialization of their child's emotion regulation (Eisenberg, Cumberland, \& Spinrad, 1998; Morris et al., 2007). Some parenting factors that have been associated with children's emotion regulation ability are parents' own emotional displays and levels of emotional expressivity (Parke, 1994). Also, parents’ level of emotional and behavior problems have been shown to be positively related to their child's inability to regulate their own emotions (Phillips \& Power, 2007). One study found that girls with more supportive parents in their sports participation had a more open, bidirectional communication with their parents (Holt, Tamminen, Black, Mandigo, \& Fox, 2009), a communication style that is associated with children's use of more constructive coping strategies (Gentzler, Contreras, Kerns, \& Weimer, 2005). Parental support in general may be related to more adaptive emotion regulation, although this needs to be further explored in father-child relationships (Darling \& Steinberg, 1993; Hardy, Power \& Jaedicke, 1993; Kliewer, Fearnow, \& Miller, 1996). Parents can also intentionally influence their children’s emotion regulation and perception of situations by reframing negative events and by promoting positive responses (Gilliom, Shaw, Beck, Schonberg, \& Lukon, 2002).

Although parental influences on children's emotions and coping with emotional events have been extensively explored by researchers and reviewed in several papers (Eisenberg, Cumberland, \& Spinrad, 1998; Morris et al., 2007; Skinner \& Zimmer-Gembeck, 2007), past research has not adequately examined the relationship of these processes in specific domains or within a sports context. One study by Holt et al. (2009) found that sports-specific parenting behaviors in girls’ soccer were not significantly related to general parenting behaviors, so understanding the influence of these context-specific behaviors and their influence on their 
children may be critical to further understanding how children handle stressors in sports and in their daily life. This study will attempt to explore sports-related and general parenting behaviors and their relation to general emotion regulation skills in their children.

\section{Parental Pressure and Support in Sports}

According to Fredricks and Eccles (2008), parents serve multiple roles in their child's sport participation and experience. They provide opportunities, influence the child’s interpretation of their sports experiences through their own reactions and attitudes, and serve as a role model as to how one should behave within a sports context. Within a high stress, competitive sports environment, parents may frequently be put in situations where they have the opportunity to provide their child with emotional support and serve as an "interpreter" of the situation (Anderson \& Anderson, 2000), which can influence the child’s perception of the experience. If a parent has an emotional reaction to an event, this in turn can influence the child's reaction, feelings, and beliefs about the incident.

Harter’s Self-Construction Model (1978) states that youth are motivated to be competent, and positive feelings are experienced when efforts to be competent are successful, whereas a lack of success leads to more negative emotional states. Children's goals that they set for themselves have been shown to be significantly related to their perceptions of their parents' expectations (Bergin \& Habusta, 2004; Nicholls, 1989). Parental support in sports that is not contingent on success may lead to more feelings of competence and more positive emotional states. Consistent with this idea, research on youth programs has suggested that supportive adults may be crucial for positive development in activities (Eccles \& Gootman, 2002), and parental support in sports and satisfaction with their child's participation has been associated with more activity enjoyment and higher levels of self-esteem (Anderson et al., 2003; Leff \& Hoyle, 1995). Another study 
found that parental support served as a buffer for stress caused by teammates for low performing athletes (VanYperen, 1995).

However, not all parents may take these opportunities to serve as a supportive role for their child. Past research found that youth swimmers with low perceptions of parental support had more maladaptive and less adaptive coping strategies (Lafferty \& Dorrell, 2006), and lowperforming athletes perceiving low levels of parental support had higher levels of stress (VanYperen, 1995). While some parents forgo these opportunities to serve as a supporting role for their child, there also is a substantial amount of research that suggests that a number of parents actually serve as an additional stressor for the child through pressure to either perform better and stay in their sport, to join a sport, or to quit (Dworkin \& Larson, 2006; Fraser-Thomas \& Cote, 2009; Gould, Lauer, Rolo, Jannes, \& Pennisi, 2006, 2008). One study that examined competitive 13 year-old skiers found that two thirds of youth reported their parents as a source of moderate or forceful pressure, and over one quarter of youth reported that their parents "forced" them to compete, many of which indicated that they were not happy with that pressure and felt apprehensive of their parents' reactions after performing poorly (Hellstedt, 1990). This parental pressure may be due to a variety of factors. For example, some parents may believe that expressing disappointment for poor performance will result in motivation for better performance in the future (Anderson et al., 2003). There is also a concept of “achievement by proxy," which, when applied to a sport setting, suggests that parents may pursue prospects for their own financial or social benefit, such as professional or scholarship opportunities, social status, or bragging rights (Anderson et al., 2003; Tofler, Knapp, \& Drell, 1998, 1999). Due to consistent increases in college tuition (National Center for Public Policy and Higher Education, 2008), pursuing potential scholarship opportunities may be especially pertinent for parents and families, 
and may continue to be a cause for parental pressure on their children to excel in their sport. Recent research has also mentioned the possibility of parents' own stress resulting in pressure placed on the child-athlete (Harwood \& Knight, 2009). In addition, parents invest a lot of time and financial resources into the child’s sport (Baxter-Jones \& Maffuli, 2003; Kirk et al., 1997; Murphy, 1999), which may lead to indirect pressure on the child to do well if they feel that their parent is sacrificing significant time and money for their participation. One study found that a higher level of parental involvement in their child's sport was associated with higher rates of the child feeling “trapped” and experiencing burnout (Coakley, 1992).

Pressure from parents is potentially detrimental for children. As previously mentioned, children's perceptions of their parents' expectations are related to the goals that children set for themselves (Bergin \& Habusta, 2004; Nicholls, 1989) Because of this association, parents who exert pressure and set unrealistic expectations for their children may lead their children to set unrealistic goals for themselves, which may lead to decreased feelings of competence and more maladaptive coping (Gaudreau \& Blondin, 2002; Gaudreau, Blondin, \& Lapierre, 2002) and more worries of failure (Lewthwaite \& Scanlan, 1989; Sagar \& Lavallee, 2010). Other research has suggested that athletes’ perfectionism in sports was associated with their parents' perfectionism in sports (Appleton, Hall, \& Hill, 2010). While sports offer a wide range of learning opportunities for kids, parental pressure may inhibit their child’s ability to grow and learn from those opportunities and instead exacerbate the negative influence of the stress that sports may cause. Two studies on tennis athletes found that in both studies, parental pressure and negative parenting behaviors were reported by coaches and these behaviors were perceived as having a negative impact on their child's development (Gould, Lauer et al., 2006, 2008). One study that examined parents' sideline behaviors found that the majority of parents experienced 
negative emotional displays such as anger and rage, displayed aggression, and were not able to regulate these emotions (Goldstein \& Iso-Ahola, 2008). Poor emotion regulation and angry displays by parents may in turn be related to more maladaptive emotion regulation in their children (Parke, 1994). Other studies have found that parents in organized sports may have a negative influence on children's sense of self, faith in others, stress levels, and overall activity experience (Grossman \& Rhodes, 2002; Leff \& Hoyle, 1995; Scanlan et al., 2005) and that parent over-involvement, high expectations, and negative evaluation of their child's performance may play a part in heightened levels of child anxiety (Gould et al., 1991; Leff \& Hoyle, 1995).

In addition to the initial effects of parental pressure, these parenting behaviors may be more problematic when prolonged (Dworkin \& Larson, 2006). Although stress in sports can come from a variety of situations, such as poor coaching, negative team dynamics and peer interactions, goal achievement, and amount of time and effort required, most children have the option of removing themselves from these stressful situations by joining a new team or switching to a new sport. However, parenting practices within sports settings will likely follow the child across teams and different sport choices, leading parent-related stress to remain. In addition, parents' views of their support and pressure behaviors towards their kids in sports have been shown to significantly differ from the amount of support or pressure that their child perceives (Kanters, Bacarro, \& Casper, 2008). Therefore parents may have a difficult time knowing if their behavior is perceived as pressure by their child, and may be likely to continue these negative behaviors.

\section{The Present Study}

Due to the high prevalence and issues associated with parental pressure that has been reported in past research and the opportunity for parents to serve as a supportive role in their 
child's participation, this study will attempt to examine the influence that these parenting practices may have on their children. Very little research has focused on these behaviors and their association with children's emotion regulation. This study will examine if parental behaviors towards their child's success, failure, and performance in sports may influence their child's overall ability to regulate their emotions in response to negative affective states, both within and outside of the sports context. Specifically, child-perceived parental support and pressure behaviors will be investigated. These two constructs are independent of one another within sport settings (VanYperen, 1995). Consequently, support and pressure will be examined to accurately assess the influence of these specific behaviors independently, as well as any interactive effects between the two behaviors.

The specific purpose of this study was to examine how varying levels of parental pressure and support in sports are associated with the emotion regulation of their children. To investigate this relationship, we examined parents' general and soccer-specific pressure and support and their child's ability to regulate their sad, angry, and worried feelings.

First, it was hypothesized that greater levels of support and lower levels of pressure in soccer would be positively related to children's reports of more adaptive emotion regulation, specifically more coping and less dysregulation of anger, sadness, and worry.

Second, the relationship between pressure in soccer and children's emotion regulation was hypothesized to be moderated by parental support in soccer. It was expected that high levels of support would be associated with less adaptive emotion regulation as reports of pressure increased. It was also expected that low levels of support would be associated with less adaptive regulation as reports of pressure increased. However, it was expected that this slope would be 
stronger for those reporting high levels of support. The direction of this hypothesized moderating relationship is exploratory in nature.

Third, the associations between soccer-related pressure and support and children's emotion regulation were expected to remain significant, even when controlling for parents’ general support and pressure behaviors.

By investigating these parental influences within this specific context, we can find ways to minimize the negative impact of stressful situations that children may encounter in their sports participation and promote positive emotional development.

\section{Method}

\section{Participants}

Ninety-one parent-child dyads were recruited from youth soccer teams in the Washington D.C. metropolitan area. There were roughly an equal number of boys and girls (42 females, 49 males), and there were more mothers than fathers (67 mothers, 23 fathers, 1 missing) that completed the study. There were 31 mother-daughter dyads, 36 mother-son dyads, 13 father-son dyads, and 10 father-daughter dyads. Children were between the ages of 8-12 $(M=10.24, S D=$ 1.19) and were primarily Caucasian (74.7\%, 9.9\% black, 6.6\% Latino, 1.1\% Asian, 2.2\% biracial, $4.4 \%$ other, $1.1 \%$ missing). To increase the likelihood that parenting behavior within a soccer domain would have an impact on children's daily life, participants were limited to players on soccer teams playing in competitive, travel leagues. The majority of participants (94.5\%) indicated that soccer was the sport that they were most involved in and on average, children had been involved in soccer for 5.51 years $(S D=1.64$, range $=1-11$ years $)$ and parents indicated that on average they spent 8.03 hours a week on their children's soccer $(S D=3.03$, range $=3-20)$. Overall, children reported that soccer was important to them (as rated on a 7-point Likert scale 
with $1=$ very important and $7=$ not important at all; $M=2.08, S D=1.67)$. Children also reported that their soccer was enjoyable to them (again, as rated on a 7-point Likert scale with 1 = very enjoyable and $7=$ not enjoyable at all; $M=2.00, S D=1.84)$.

\section{Procedure}

Once permission from coaches and tournament directors was granted, members of the research team attended tournaments, games, and practices of teams. Researchers talked to parents and children about the study and those who volunteered to participate were given a packet of questionnaires that were explained to them by a member of the researcher team. If more than one parent was present at the game or practice, it was asked that the parent that was most involved in the child's soccer participated. They were encouraged to complete the questionnaires on-site with a member of the research team present and available to answer questions; however, some participants elected to mail the questionnaires to the researchers at a later date. Parents and children were instructed not to share answers or help one another with the questions. For those who elected to complete the survey by mail, separate envelopes were provided for children and parents to protect confidentiality. Children received \$5 and were entered in a \$100 raffle for participating.

\section{Measures}

Demographics. Parents completed several demographic questions on their relationship to the child, information about children's age, race, sex, and family, as well as information on SES (assessed by a single item, “On a scale of 1-7, with 1 being very difficult and 7 being not difficult at all, how hard is it for you to pay your monthly bills?”).

Soccer involvement. Parents were asked to answer several items related to their family’s involvement in soccer, such as their time and financial involvement, and the importance of the 
sport to their child. Children were also asked to complete similar items on their family's soccer involvement. The demographic and soccer involvement questions can be found in Appendices A and B.

Emotion regulation. Children`s emotion regulation was measured using the Children`s Emotion Management Scales for Anger, Sadness, and Worry (CAMS, CSMS, and CWMS; Zeman, Shipman, Suveg, 2002; Zeman, Shipman, Penza-Clyve, 2001; Zeman, Cassano, Suveg, \& Shipman, 2010, respectively. See Appendices C, D, and E). Each of these scales are selfreport measures ranging between 10-12 items and focus on a specific negative emotion. Each scale separates different emotion regulation strategies into 3 subscales: inhibition, dysregulation, and coping. Coping refers to the adaptive regulation of the particular emotion experienced, whereas dysregulation refers to the nonconstructive and exaggerated expression of the particular emotion (e.g., Zeman et al., 2001; Zeman et al., 2010). Inhibition refers to suppressing or hiding the expression of the specific emotion being experienced (Zeman et al., 2001). Although inhibition of emotion is usually associated with negative outcomes (e.g., Zeman et al., 2001), the adaptibility of inhibitory responses might vary depending on the appropriateness of the emotion in the current situation (e.g., Gross, 1998). Therefore, the current study used the dysregulation and coping scales only.

Child participants were asked to identify how often they do or feel certain things when they are feeling either mad, sad, or worried on a 3-point scale (hardly-ever, sometimes, and often). Some examples of questions include, “I stay calm and don’t let sad things get to me“ (coping), and “I can’t stop myself from acting really worried“ (dysregulation). Three items from the scales were not reliable in the current study. One item was from the sadness dysregulation subscale ("When I'm sad, I do something totally different until I calm down") and the removal of 
this item increased the reliability from .41 to .53. Another item was removed from the sadness coping subscale ("I do things like mope around when I'm sad”) and increased the reliability from .48 to .57 . The last item was from the worry coping subscale ("I talk to someone until I feel better when I'm worried”) and increased the reliability from .02 to .42. With these items removed, coefficient alphas for the subscales ranged from .42-.63. Each of these scales have shown good construct validity for Caucasian, middle class, 6-12 year old populations, and Cronbach alphas for these scales usually range from .60 to .77 (Zeman et al., 2010; Zeman at al., 2001; Zeman et al., 2002).

Parental pressure. Parental pressure was measured using subscales of two versions of the Multidimensional Perfectionism Scale (MPS). To address sports-specific pressure, the subscale for perceived parental pressure from the Sport-MPS-2 was used (Gotwals \& Dunn, 2009; see Appendix F). This subscale includes 9 self-report items derived from the parental criticism and parental expectations scale of the Frost-MPS (Frost, Marten, Lahart, \& Rosenblate, 1990). Child participants were asked to rate the extent to which they agree or disagree with certain statements on a 5-point scale (strongly agree, agree, neither agree nor disagree, disagree, or strongly disagree) about the parent participating in the study with them. These items were modified to refer to soccer specifically, as opposed to general sport pressure. Examples of these items include, “In soccer, I never feel like I can quite meet my parents’ expectations,“ and, “I feel like I am criticized by my parents for doing things less than perfectly in soccer.“ This subscale had a coefficient alpha of .82 and has been previously validated for use with young adolescents (Dunn et al., 2006; Gotwals \& Dunn, 2009).

To assess general parental pressure, the parental criticism and the parental expectations subscales of the Frost-MPS were used (Frost et al., 1990; see Appendix G). Each of these item`s 
phrasing and scoring are comparable to the sport adapted versions in the perceived parental pressure subscale of the MPS-Sport-2. Questions were retrospective items, and were adapted to indicate current perceived parental criticism and expectations by the child about the parent completing the study with them. Some examples of questions include, "My parents set very high standards for me,“ and, "My parents always have higher expectations for my future than I have.“ Like the Sport-MPS-2, these subscales of the Frost-MPS have been validated for use with early adolescents (McArdle \& Duda, 2008) and the coeffiecient alpha was for this scale was .80.

Parental support. Parental support was measured by the parent subscale of the Children and Adolescent Perceived Social Support Scale (CASSS; Malecki \& Demaray, 2002; see Appendix H). The subscale has 12 child-report items assessing emotional, informational, appraisal, and instrumental support from a parent. For each item, the child rated on a 6-point scale how often they perceive that type of support from the parent participating in the study with them (never, almost never, some of the time, most of the time, almost always, and always), and on a 3-point scale how important getting that type of support is to them (not important, important, and very important). However, for the purposes of this study, only the frequencies of support behaviors were analyzed. Some examples of items are, "My parent listens to me when I need to talk," “My parent rewards me when I’ve done something well,” and, “My parent makes suggestions when I don’t know what to do.” To more comprehensively assess the emotional component of support in light of failure or lack of success (which may be a common circumstance in sports participation), 4 additional items were added to the questionnaire (items 13-16). Past research has suggested that the CASSS is appropriate for children in grades 3-12 and that it shows strong construct validity (Malecki \& Demaray, 2002). The coefficient alpha for 
this measure and the three additional items was .87 (Cronbach's alpha without the 4 additional items was .81).

To assess perceived parental support in a soccer setting, all of the items from the parent subscale of the CASSS were adapted (see Appendix I) along with the additional 4 emotional support items. Some examples of items include, “My parent understands me about soccer-related problems,” and, “My parent tells me I did a good job when I do something well in soccer.” The coefficient alpha for this measure and the 4 additional items was .89 (Cronbach's alpha without the 4 additional items was .85). Parents were also asked to fill out measures of both sport-related and general self-reported support and pressure; however, parent-report of these constructs were not examined in this particular project.

Other. Parents also completed measures on children’s general functioning and difficulties, children’s empathy, and children’s responses to positive events. These measures were not examined in the current study.

\section{Results}

\section{Data Cleaning and Preliminary Analyses}

Two families’ data were removed entirely, resulting in the final 91 participants. One dyad was removed because both the parent and the child circled the same responses for every item in every scale. One dyad was removed because the child circled all of the responses down the center, and the parent routinely circled multiple answers. Data were also screened for participants that indicated that they did not understand any of the questions or for children who indicated that their parent helped them with some of the items. When participants indicated that this occurred, the problematic item or items were removed from those specific participants’ responses and were treated as a missing variable to ensure the accuracy of responses used in the 
analyses. One dyad's child responses were removed because the child indicated that they did not understand any of the questions. For one participant, both the general parent pressure and soccerrelated parent pressure scales were removed because the parent and child both indicated that they did not understand the questions. Several of the child participants $(n=5)$ indicated that one specific item was difficult to understand or that their parent helped them with a particular item. There were no apparent patterns in the items that participants had difficulty with.

There was a small amount of missing data $(<5 \%)$. However, a large number of participants did not answer the demographic question on SES (18.7\%). Lack of response to this question was not related to any of the other variables of interest. For participants who were missing items from a scale, the scale mean for that participant was imputed for this missing item when $66.66 \%$ or more of the scale had been completed. Subsequent analyses were conducted using listwise deletion.

Data were tested for normality, outliers, issues with multicollinearity, homoscedasticity, linearity, and the independence and normality of errors by examining descriptive statistics, histograms, Q-Q plots, scatterplots, and bivariate correlations. Descriptive statistics and bivariate correlations are presented in Table 1.

Two variables were significantly negatively skewed (general support, soccer-related support) and one variable was significantly positively skewed (worry dysregulation). Both general and soccer-related supports were transformed by reflecting the variables and using a square root transformation, which fixed the skewness for both variables. Worry dysregulation was log transformed which also fixed the skewness. However, results did not differ depending on whether or not the variable was transformed, so the raw variables were retained for the following analyses reported. There were also 3 sets of siblings in the study, violating the assumption of 
independence. All analyses were conducted with the siblings included and with one from each set removed (the sibling removed was chosen at random). The findings did not differ based on whether or not siblings were included, so the following analyses reported include the full sample.

Bivariate correlations and independent sample $t$-tests were conducted to assess whether child participants varied on the constructs of interest by children's gender, parent gender, age, or SES. Children's gender, parent gender, and children’s age were all unrelated to children’s reports of support, pressure, and emotion regulation. Two-factor ANOVAs indicated that parent pressure and support did not differ when considering different gender combinations of the parent-child dyads. In other words, mother-daughter, mother-son, father-daughter, and father-son dyads did not differ on the amount of pressure or support in soccer reported by children. Children's reports of pressure in soccer was correlated with SES, $r=-.30, p<.05$, with higher reports of parent pressure in soccer relating to parent's reporting a more difficult time paying their monthly bills. Therefore, SES was included as a covariate in the following analyses.

\section{Support and Pressure in Soccer Predicting Children’s Emotion Regulation}

To assess child-reported parent support and pressure in soccer and their ability to predict children’s emotion regulation abilities, six multiple regression analyses were conducted with each type of emotion regulation ability (anger coping, anger dysregulation, sadness coping, sadness dysregulation, worry coping, worry dysregulation) as an outcome variable in each analysis. In the first step of each regression, soccer-related pressure and support (both centered around the mean) were entered into the regression equation. In the second step of the regression equation, SES was included as a covariate. In the third step, an interaction term between both parent pressure and support in soccer was included in the equation. Finally, general parent support and general parent pressure were entered into the fourth and final step of the model to 
assess if any significant associations found between soccer-related parenting behavior and emotion regulation hold even when controlling for general parenting behaviors. The final models from these regression equations can be found in Tables 2-4. Due to the correlations between general pressure and support and between sport-specific parenting and general parenting, colinearity statistics were examined for signs of potential multicolinearity issues. For all of the final models, the tolerance level ranged between .46-.86. The variance inflation factor ranged from 1.16-2.17. The condition indices ranged from 1.23-6.27. These values suggest that despite significant correlations among several of the predictor variables, multicolinearity is likely not an issue in these analyses.

Parental support and pressure were unrelated to both anger coping and anger dysregulation (see Table 2). When examining the association between parenting behavior and sadness regulation, pressure and support in soccer were unrelated to sadness coping. However, general support was a significant predictor of sadness coping in that more general support from parents was associated with more coping with sadness. When predicting sadness dysregulation, soccer-related pressure was marginally significant, with higher reports of pressure associated with more dysregulation. However, this effect no longer approached significance when controlling for general parenting in the final step of the model. Overall, with all of the variables included in the model the only significant predictor of sadness dysregulation was general parent pressure, with higher reports of pressure predicting more dysregulation of sadness (see Table 3).

Coping with worry was significantly predicted by pressure in soccer, although this effect only marginally significant after controlling for general parenting. There was also a significant interaction between support and pressure in soccer when predicting children's ability to cope with worry. In the context of low support, pressure was more strongly associated with coping 
with worry than when children reported higher levels of support in soccer. Specifically, with low support, higher levels of pressure were associated with less coping with worry than lower levels of pressure. However, when children were reporting high levels of support in soccer, pressure was positively related with coping with worry. In other words, more pressure was associated with more coping with worry. However, a simple slopes analysis of this interaction indicated that although the slopes of pressure regressed onto worry coping were significantly different at high and low levels of support, neither of these slopes differed significantly from zero. This interaction is displayed in Figure 1. When predicting worry dysregulation, soccer-related support was a significant predictor, but only after the last step of the regression model when controlling for general parenting. However, contrary to the hypothesized direction, higher reports of support were associated with more worry dysregulation.

\section{Discussion}

Past research has indicated that children may encounter more negative experiences in sports as opposed to other organized activities, which might provide a context in which children have the opportunity to learn valuable skills related to emotion regulation (Dworkin, Larson, \& Hansen, 2003; Hansen et al., 2003). It has also been suggested that parenting behaviors can alter the affective experience that children have in their sports participation (Anderson \& Anderson, 2000), which may impact opportunities for emotion regulation learning. According to Fredricks and Eccles (2008), parents can influence the stressful experiences children face in sports in several ways. They could potentially help children ameliorate stress by providing support that is not contingent on their success, they can become an additional stressor by placing pressure on the child to do well, or they could model appropriate and inappropriate behaviors to handle stress. The purpose of the current study was to examine children's reports of parental support and 
pressure in soccer and how these behaviors related to children's coping and dysregulation of anger, sadness, and worry when controlling for general parenting behaviors. This study expanded on past research by examining parenting behaviors in a specific domain and how this was associated with children’s general emotion regulation.

This study had several strengths. First, the inclusion of both fathers and mothers in the study allowed for investigation of gender differences in pressure and support in soccer for both child and parent gender. Second, this study examined parent pressure and support as two separate constructs, which allowed for examination of the independent influence of each on children's emotion regulation as well as interactive effects between the two types of parenting behaviors. Third, these pressure and support behaviors were examined across domains, specifically, children reported on their parents' pressure and support in soccer and in general day-to-day life. The inclusion of general parenting behaviors made it possible to parcel out the variance in children's emotion regulation accounted for by these general parenting behaviors to determine if parenting behaviors in soccer influenced children's emotion regulation beyond that domain. Fourth, while many studies have examined sports-specific parenting and its implications for that child's sports participation and sports experience, this study examines sports-specific parenting and implications that it may have beyond their sports participation. Fifth, sadness, anger, and worry regulation were considered separately in this study, resulting in greater specificity in the emotion regulation construct. Some researchers contest that the regulation of discrete emotions should be considered separately due to different processes associated with each emotion that lead to emotion-specific regulatory tasks (e.g., Cisler, Olatunji, Feldner, \& Forsyth, 2010; Izard et al., 2011), and reports of emotion regulation tend to vary based on the specific emotion experienced (Levine, Stein, \& Liwag, 1999). 
In the current study, it was hypothesized that greater levels of support and lower levels of pressure in soccer would be positively related to children's use of more adaptive emotion regulation. It was also hypothesized that these associations between soccer-related pressure and support and children’s emotion regulation would be present over and above parents’ general support and pressure behaviors. With children's anger regulation, both general and soccerspecific parenting behaviors were unrelated to anger coping and dysregulation. For children’s sadness regulation, parenting behavior in soccer was unrelated to sadness coping and dysregulation after controlling for general parenting behaviors. Soccer-specific pressure was marginally associated with sadness dysregulation, with more pressure being associated with more dysregulation. However, this association was no longer marginally significant after accounting for general pressure behavior. In contrast, more general support was associated with more ability to cope with sadness.

The lack of findings for anger and sadness were surprising. Past research has shown that background anger during sporting events is common (Omli \& LaVoi, 2009) and that parents display unregulated anger on the sidelines of games (Goldstein \& Iso-Ahola, 2008), which may model unregulated behaviors for their children, teach them that this anger is acceptable, and lead to less regulation of this emotion (Parke, 1994). However, these behaviors may have not been specifically directed at the child. Potentially, parents may display more anger related to sports during the "heat of the moment” during games, when children are distracted and likely less influenced by parenting behaviors. The pressure behaviors assessed in this study specifically tapped into how the child perceived their parents expectations of them and the criticism they received if they did not meet those expectations, and the support behaviors tapped into instrumental, appraisal, informational, and emotional support of the child. Specific anger 
reactions or sadness in the parent or their active regulation of these emotions were not assessed directly, which may be stronger predictors of their children's emotion and its regulation. Parents' reactions to their children's emotions in sports, such as coaching or punishing responses, may also be predictive of children's emotion regulation. However, those behaviors were not assessed directly either.

Parental behaviors in soccer showed the most significant associations with children’s regulation of worry. More parental support in soccer was associated with more worry dysregulation, which is the opposite of the hypothesized direction of this effect. However, this effect only emerged after including parent general support in the model, which was predictive of less worry dysregulation. It is possible that if soccer is the only context in which the child is receiving support that they will be more likely to feel like they need to succeed within this domain. It is possible that this involvement in soccer may lead to indirect pressure on the child to do well if they feel that their parent is sacrificing significant time, money, or emotional effort for their participation. The level of involvement in this study was high, with the majority of participants indicating that soccer was the sport that the child was most involved in and that the sport was important to them, and families indicated that they spent about 8 hours a week on their child's soccer on average. It is possible that more instrumental parental behaviors related to high levels of involvement, such as buying their child the equipment that they need in soccer and making suggestions about soccer-related issues, might be perceived by children as implying that they to do well in their sport. This interpretation is consistent with past research which has highlighted negative outcomes associated with higher levels of parent involvement, such as feeling “trapped” and experiencing burnout (Coakley, 1992). Again, higher support in soccer was only associated with worry dysregulation in the context of low general support. This 
suggests that these supportive behaviors in soccer are only problematic when children are not receiving general support in their day to day life from this parent.

Results indicated that more parental pressure in soccer was marginally associated with children's lessened ability to cope with worry. This is consistent with past research, which suggests that negative parenting behaviors may be related to more worry-related feelings in their children. For example, negative parenting behaviors and evaluations of their children in sports are associated with more worry and fear of failure by the athlete (Lewthwaite \& Scanlan, 1989; Sagar \& Lavallee, 2010) and youth athletes’ perfectionism in sports is associated with their parents’ perfectionism in sports (Appleton et al., 2010), which may also lead to more worry about failing. While past research has only examined how these parenting behaviors in sports influence children's thoughts about sports-related outcomes only, past research has indicated that some youth have difficulties preventing negative emotions from their sports spill over into their non-sport life (Dworkin \& Larson, 2006). This study did not assess sports-related regulation, but less adaptive regulation of worry in sports may lead to less general adaptive regulation as well.

It was also hypothesized that the influence of pressure in soccer on children's emotion regulation would be moderated by parental support in soccer, with children reporting high levels of pressure and high levels of support in soccer also reporting less adaptive emotion regulation than those reporting low levels of pressure and high levels of support. A significant interaction emerged between parental pressure and support in soccer when predicting coping with worry.

As previously mentioned, pressure in soccer was related to less coping with worry, and this relationship was stronger for those who were also reporting low levels of support. However, for those reporting high levels of support, more pressure was actually associated with more coping with worry. Despite the significant interaction, neither of the slopes were independent 
predictors of coping with worry when considered separately, perhaps due to insufficient power. Because of the nonsignifcant simple slopes analyses, the interpretation of this interaction is extremely speculative and these results and their explanations should be considered with caution. Nevertheless, this interactive effect might have implications for parental involvement in their children’s sports. Supportive behaviors may mitigate the negative outcomes associated with high pressure behaviors. Recent focus groups conducted on 12-15 year-old tennis players found that these children preferred their parents to provide supportive advice and comment on their effort and attitude (Knight, Bolden, \& Holt, 2010). This suggests that children might like at least some level of supportive involvement by their parents, and that the absence of these supportive behaviors might make negative experiences in their sport, such as pressure from their parent, more detrimental.

Parental support and pressure in soccer were not related to one another, which indicates that some parents may be engaging in behaviors that support and pressure their child simultaneously. This is consistent with prior research on parenting behaviors in soccer (VanYperen, 1995). However in the present study general support and pressure were negatively associated. The lack of correlation between these behaviors in soccer in conjunction with the significant interaction between support and pressure suggests that future research should continue to examine these types of behaviors in sports as separate constructs, and furthermore might consider continued examination of the relationship between these independent constructs and how they may differentially predict child outcomes. In line with these findings, perceived pressure from parents might be especially detrimental when there is also a lack of support. When examining the relationship between general and soccer-specific parenting behaviors, support and pressure were correlated across domains. This is contrary to previous 
research which found that sport-specific parenting behaviors in girls’ soccer was not related to general parenting behaviors (Holt et al., 2009). However, many of the children in this study completed these questionnaires after practices and games, so it is possible that when reporting on general parenting behavior they were more likely to recall instances of their parents' behavior that was related to soccer (although precautions were taken against this by having the children answer the general questions before the soccer-related questions).

No gender effects were found in this sample. These gender differences were examined by comparing the variables of interest based on child gender, parent gender, and the dyadic relationship (mother-son, mother-daughter, father-son, father-daughter). This lack of effect by gender was surprising, especially because past research has highlighted differences in emotion regulation in boys and girls, and different emotion socialization processes by mothers and fathers (e.g., Chaplin, Cole, \& Zahn-Waxler, 2005; Eisenberg et al., 1998; Morris et al., 2007). However, the small number of father-son and father-daughter dyads may have potentially limited the power available to detect such an effect.

Another surprising result was the lack of significant age differences in this sample regarding the variables of interest. Past research on children ranging in ages from 7-10 and about 6-10 has indicated that as children get older they are able to more adaptively communicate their emotional experiences (Shipman, Zeman, Nesin, \& Fitzgerald, 2003; Zeman \& Garber, 1996). However, this was not the case in this particular study, at least according to children's selfreports. The families that were sampled in the study were able to provide adequate financial support and invest the time needed to be involved in a competitive sport, and therefore they might have a higher baseline level of economic functioning than the average family, which tends to be associated with better child outcomes (e.g., McLoyd, 1998). This may have resulted in a 
limited range of variability in emotion regulation. Also, soccer participation may include more negative experiences than other activities (Hansen et al., 2003; Larson et al., 2006; Smith, Smith, \& Smoll, 1985). Children with maladaptive emotion regulation skills may not have been able to adequately cope with these experiences and may have discontinued participation or chosen less competitive teams where negative experiences associated with achievement were less likely to occur. This may have also resulted in a limited range of variability in emotion regulation. The children in this sample were reporting, on average, that soccer was very enjoyable to them, which may be indicative of this self-selection bias that could have result in limited variability in emotion regulation skills. There were also no age differences in children's reports of parent behavior. Again, this may be due to a self-selection bias in which children who experience maladaptive patterns of parenting behaviors may be more likely to discontinue or decrease participation at an earlier age. The presence of background anger in sports tends to increase from the ages 8-18 (Omli \& LaVoi, 2009). Potentially, the range of ages in this study may have been too restricted to uncover any age effects in reports of parenting behaviors.

One unexpected finding that emerged was the significant association between SES and children's reports of parent pressure in soccer. Specifically, parents who reported that they had a more difficult time paying their monthly bills had children who reported that their parents pressured them more in soccer. There are quite a few possible explanations for this relationship. It is possible that parents who are experiencing more financial distress might place more emphasis on success if it may lead to college scholarship opportunities in the future. This is consistent with the idea that parents might look at their children's success as something that may allow them to benefit as parents in some way as well (Tofler, Knapp, \& Drell, 1998, 1999). Parents who might have a difficult time paying for their child's college in the future might be 
more likely to focus on this opportunity. It is also possible that parents who have a harder time paying their bills have to sacrifice more financially in order to afford their children's soccer, and may therefore place more emphasis on how the child performs. If a parent is investing a lot of resources into this activity, it might be more of an issue to that parent if they feel that the child is not putting forth enough effort or playing to the best of their ability. It may also be the case that the pressure that children in lower SES families are perceiving might be more indirect. Perhaps children who know that their parents are investing more financially in their soccer might inadvertently feel like they need to perform at a high level to justify the amount of money that their parents are spending on them. Future research should continue to examine this relationship and could further explore how parents’ feelings towards their children’s success might vary based on their investment in their sport, or how children's view of their own success might vary based on their perceived family investment.

\section{Limitations}

There are quite a few limitations to this study that should be taken into account when interpreting results. One is that the sample size may have been too small to detect some effects. There were several variables that were approaching significance. Also, despite a significant interaction between support and pressure in soccer when predicting coping with worry, the simple slopes analysis indicated that both slopes were nonsignificant. It is possible that with a larger sample, there would be sufficient power to reveal the exact nature of this interactive effect. Additionally, while this study expanded on the current literature on the socialization of emotion regulation by examining fathers in addition to mothers, this study lacked sufficient power to test for parent and child gender effects. 
Another limitation of this study is that the sample is very limited in its generalizability. This study looked at competitive soccer players only, and the results may not generalize to those who engage in other achievement-related activities (i.e., music), less competitive players, or those engaging in different sports (i.e., individual versus team sports). In addition, self-selection in the sample might have had a confounding effect on the results. Those who choose to play sports may be different than children who choose to participate in other activities or who choose to not participate in any activities at all. Previous research suggests that children who are less emotionally adjusted and who self-report more depressive symptoms spent less time in organized activities a couple years later (McHale, Crouter, \& Tucker, 2001; Posner \& Vandell, 1999). Although some research suggests that children may experience more negative behaviors from others in sports, including parents, as they get older (Omli \& LaVoi, 2009), it is possible that children who suffer from emotional difficulties or who are perceiving a significant amount of negative parenting behaviors may have dropped out of sports participation by the age period examined in this study. However, the select number of children who may remain in their sport despite these negative parenting behaviors might show increased difficulties with age due to cumulative effects of those experiences, although future research should investigate this further.

There are also several limitations with the method of this study. Parent-report of parents' soccer-related behaviors were also assessed, although with limitations due to sample size, these reports were not utilized in analyses. However, child and parent reports of support and pressure in soccer were not significantly correlated in this study, indicating that parents and children were reporting different levels of these behaviors from one another. This study examined only childreport because children's perceptions of parenting behaviors might have more of an impact on the child. For example, if parents are partaking in particular supportive behaviors but these 
behaviors go unrecognized by the child, they will likely have little direct impact on the child. It is unclear if children are more or less accurate in their reports of parenting behavior, although future research could use a third source of data, such as coaches or observational measures.

This study also only examined self-reported emotion regulation, which is susceptible to reporting biases. Examining behavioral, physiological indicators, or using multiple reporters of regulation ability in addition to self-report may have lead to a more accurate assessment of emotion regulation. Past research has highlighted that assessing child behavior can be a challenge due to the tendency for different informants to report unique and nonoverlapping information about the behavior of choice (e.g., Hourigan, Goodman, \& Southam-Gerow, 2011; Kerr, Lunkenheimer, \& Olson, 2007). This may have been an especially limiting factor in this study due to the low reliability of the emotion regulation measure used. Potentially, only using child-report for this construct may have also resulted in some method variance since the parent pressure and support variables examined were also child-report. Despite only using one informant, however, child report may have been the best option (despite social desirability biases) because often times if children are regulating their emotions adaptively, parents might not recognize the presence of the emotion in the first place. This may be especially true since the only emotions assessed were negative emotions (anger, sadness, fear) which may not be socially acceptable in many situations and call for more regulation when experiencing them.

This study also did not assess how children's behavior might have had an impact on their parents’ behaviors. Past research on youth sports has shown that children have reciprocal influences on parenting behaviors (Holt et al., 2009), yet this study did not assess child-related variables that might be impacting their parents' behaviors in sports. Another limitation is that pressure and support were only assessed for one parent. If only one parent was present, they were 
asked to complete the study with their child, and if both were present the parent who is "most involved" in their child's soccer was asked to participate. However, past research suggests inconsistencies in some families' mother and father parenting styles in sports (Holt et al., 2009). Varying combinations of support and pressure from each parent might be differentially predictive of children's emotion regulation ability when examined in conjunction with one another. Additionally, players may experience pressure or support from other sources as well, such as teammates, other parents on their team, and coaches. Assessing these types of experiences might be beneficial as some research suggests that in a soccer context, children ranging from 8-18 years of age might commonly encounter angry interactions at events from a variety of sources (Omli \& LaVoi, 2009).

Due to the correlational design of this study, information concerning causality is lacking. Additionally, all of these assessments are concurrent, so there is no way to examine if parenting behaviors are leading to emotion regulation change, or if children's emotion regulation precedes parenting behavior. Also, previous research indicates that negative experiences in sports, such as parental pressure, may be more problematic when prolonged (Dworkin \& Larson, 2006). Again, the concurrent nature of the data does not provide information on how the perception of these behaviors over time may in turn impact emotion regulation. For most participants, their data was collected after a practice or game. It is possible that children could be reporting on the most recent behaviors that come to mind, as opposed to the average amount of pressure or support they generally feel from their parents, which may have more of an impact on children's emotion regulation ability.

Finally, one major factor that limits the conclusions from this study is that there is no comparison group to which we can compare these children. While these children are 
experiencing differential emotion regulation based on parenting behavior in soccer, we do not know how their emotion regulation ability compares to the general population or to children their age who are not engaging in sport participation. It is possible that the sample may, on average, have better (or worse) emotion regulation than a comparison group. While the current literature on sports involvement has highlighted negative and positive outcomes associated with sports participation when compared to other extracurricular activities or no activity involvement, the current study is unable to contribute any additional information related to discrepancies across different activities.

\section{Implications and Future Directions}

The results of this study have quite a few implications for children and their emotion regulation. This study expands on past research on the socialization of children's emotion regulation by examining parenting behaviors in a domain-specific area, while controlling for general parenting behaviors. These results suggest that domain-specific parenting behaviors might have consequences for their children in their daily affective experiences. Although parental influences on emotion have been explored extensively (i.e., Eisenberg, Cumberland, \& Spinrad, 1998; Morris et al., 2007; Skinner \& Zimmer-Gembeck, 2007), past research has not adequately examined the relationship of these processes in a sports context. Future research should continue to explore the relationship between parenting behaviors and emotion regulation within specific domains such as competitive soccer participation, as well as expand this to other specific achievement-oriented domains and activities, such as music, theatre, and individual sports. Although age was not associated with any of the variables of interest in this study, the range might have been too restricted to uncover any age effects. Future research should examine a broader range of ages and the relationship between parenting behaviors and emotion regulation 
in these domains. It is possible that these support and pressure behaviors and their affective consequences might differ during certain transition points in the child's sport participation (i.e., starting high school, trying to get a college scholarship).

Although this study found that parenting behaviors in this specific context were related to children's general emotion regulation, the process by which this occurs is unknown. Potentially, sports participation may provide opportunities to learn positive regulation skills, and parents may provide examples for children on how to handle negative emotions in these scenarios through their own emotional displays and levels of emotional expressivity (Parke, 1994; Phillips \& Power, 2007). Parents who cannot control their own negative emotions might provide examples of maladaptive regulatory behaviors to their children at soccer events. Additionally, by not regulating their own emotions in adaptive ways, they may be providing fewer opportunities for their children to learn more adaptive regulation skills. These responses that children encounter in sports with their parents may then be generalized to daily emotion regulation. Future research should examine this relationship between children's sport-specific emotion regulation and general emotion regulation.

Although associations between soccer-specific parenting behavior and anger and sadness regulation were not significant in this study, these results suggest that parenting behaviors within sports has an impact on children's regulation with worry. Specifically, child-report of parent pressure in soccer was related to a lower ability to cope with worry; however, this effect was attenuated when children were also reporting high levels of parental support in soccer, which suggests that support could serve as a protective factor. Additionally, higher reports of parent's support in soccer were associated with more dysregulation of worry for children when they perceived lower levels of support in general. Future research should continue to examine these 
associations and help develop interventions to promote parent's positive sport involvement in a way that will benefit their children’s emotional development. 


\section{References}

Anderson, C. \& Anderson, B. (2000). Will you still love me if I don't win? Dallas, TX: Taxler Publishing Company.

Anderson, J. C., Funk, J. B., Elliott, R., \& Smith, P. H. (2003). Parental support and pressure and children's extracurricular activities: Relationships with amount of involvement and affective experience of participation. Journal of Applied Developmental Psychology, 24, 241-257.

Appleton, P. R., Hall, H. K., \& Hill, A. P. (2010). Family patterns of perfectionism: An examination of elite junior athletes and their parents. Psychology of Sport and Exercise, $11,363-371$.

Barber, B. L., Eccles, J. S., \& Stone, M. R. (2001). Whatever happened to the Jock, the Brain, and the Princess? Young adult pathways linked to adolescent activity involvement and social identity. Journal of Adolescent Research, 16, 429-455.

Bartko, W. T., \& Eccles, J. S. (2003). Adolescent participation in structured and unstructured activities: A person-oriented analysis. Journal of Youth and Adolescence, 32, 233-241.

Baxter-Jones, A. D., \& Maffuli, N. (2003). Parental influence on sport participation in elite young athletes. Journal of Sports Medicine and Physical Fitness, 43, 250-255.

Beedie, C. J., Terry, P. C., \& Lane, A. M. (2000). The profile of mood states and athletic performance: Two meta-analyses. Journal of Applied Sport Psychology, 12, 49-68.

Bergin, D. A., \& Habusta, S. F. (2004). Goal orientations of young male ice hockey players and their parents. Journal of Genetic Psychology, 165, 383-397.

Blanchard, C., Perreault, S., \& Vallerand, R. J. (1998). Participation in team sport: A selfexpansion perspective. International Journal of Sport Psychology, 29, 289-302. 
Brewer, B. W. (1993). Self-identity and specific vulnerability to depressed mood. Journal of Personality, 61, 343-364.

Burton, D. (1998). Measuring competitive state anxiety. In J. L. Duda (Ed.), Advances in sport and exercise psychology measurement (pp. 129-148). Morgantown, WV: Fitness Information Technology.

Burton, J. M., \& Marshall, L. A. (2005). Protective factors of youth considered at risk of criminal behaviour: Does participation in extracurricular activities help? Criminal Behaviour and Mental Health, 15, 46-64.

Chaplin, T. M., Cole, P. M., \& Zahn-Waxler, C. (2005). Parental socialization of emotion expression: Gender differences and relations to child adjustment. Emotion, 5, 80-88.

Cisler, J. M., Olantunji, B. O., Feldner, M. T., \& Forsyth, J. P. (2010). Emotion regulation and the anxiety disorders: An integrative review. Journal of Psychopathology and Behavioral Assessment, 32, 68-82.

Cicchetti, D., Ackerman, B. P., \& Izard, C. E. (1995). Emotions and emotion regulation in developmental psychopathology. Development and Psychopathology, 7, 1-10.

Coakley, J. (1992). Burnout among adolescent athletes: A personal failure or social problem? Sociology of Sport Journal, 9, 271 -285.

Cole, P. M., Martin, S. E., \& Dennis, T. A. (2004). Emotion regulation as a scientific construct: Methodological challenges and directions for child development research. Child Development, 75, 317-333.

Danish, S. J., Taylor, T. E., \& Fazio, R. J. (2003). Enhancing adolescent development through sports and leisure. In G. Adams \& M. Berzonsky (Eds.), Blackwell handbook of adolescence (pp. 92-108). Malden, MA: Blackwell. 
Darling, N., Caldwell, L. L., \& Smith, R. (2005). Participation in schoolbased extracurricular activities and adolescent adjustment. Journal of Leisure Research, 37, 51-76.

Darling, N., \& Steinberg, L. (1993). Parenting style as context: An integrative model. Psychological Bulletin, 113, 487-496.

Denham, S. A., Blair, K. A., DeMulder, E., Levitas, J., Sawyer, K., Auerbach-Major, S., et al. (2003). Preschool emotional competence: Pathway to social competence. Child Development, 74, 238-256.

Duda, J. L., \& Ntounumis, N. (2005). After-school sport for children: Implications of a taskinvolving motivational climate. In J. Mahoney, R. Larson, \& J. Eccles (Eds.), Organized activities as contexts of development (pp. 311-330). Mahwah, NJ: Erlbaum.

Dunn, J., Dunn, J. C., Gotwals, J. K., Vallance, J., Craft, J. M., \& Syrotuik, D. G. (2006). Establishing construct validity evidence for the Sport Multidimensional Perfectionism Scale. Psychology of Sport and Exercise, 7, 57-79.

Dworkin, J.B., \& Larson, R. (2006). Adolescents’ negative experiences in organized youth activities. Journal of Youth Development, 1. Retrieved December 27, 2009 from http://www.nae4ha.org/directory/jyd/jyd_issues.aspx

Dworkin, J.B., Larson, R., \& Hansen, D. (2003). Adolescents' accounts of growth experiences in youth activities. Journal of Youth and Adolescence, 32, 17-26.

Eccles, J., \& Barber, B. (1999). Student council, volunteering, basketball, or marching-band: What kind of extracurricular involvement matters? Journal of Adolescent Research, 14, 10-43.

Eccles, J., \& Gootman, J. A. (2002). Community programs to promote youth development. Washington, DC: National Academies Press. 
Eisenberg, N., Cumberland, A., \& Spinrad, T. L. (1998). Parental socialization of emotion. Psychological Inquiry, 9, 241-273.

Eisenberg, N., Cumberland, A., Spinrad, T. L., Fabes, R. A., Shepard, S. A., Reiser, M. ... Guthrie, I. K. (2001). The relations of regulation and emotionality to children's externalizing and internalizing problem behavior. Child Development, 72, 1112-1134.

Eisenberg, N., Spinrad, T. L., \& Morris, A. S. (2002). Regulation, resiliency, and quality of social functioning. Self and Identity, 1, 121-128.

Eubank, M., \& Collins, D. (2000). Coping with pre- and in-event fluctuations in competitive state anxiety: a longitudinal approach. Journal of Sports Sciences, 18, 121-131.

Ewing, M. E., \& Seefeldt, V. (2002). Patterns of participation in American agency-sponsored youth sports. In F. Smoll \& R. E. Smith (Eds.), Children and youth in sport: A biopsychosocial perspective (2nd ed., pp. 39-60). Dubuque, IA: Kendall/Hunt.

Fauth, R. S., Roth, J. L., \& Brooks-Gunn, J. (2007). Does the neighborhood context alter the link between youths’ after-school time activities and developmental outcomes? A multilevel analysis. Developmental Psychology, 43, 760-777.

Fraser-Thomas, J., \& Cote, J. (2009). Understanding adolescents' positive and negative developmental experiences in sport. The Sport Psychologist, 23, 3-23.

Fredricks, J.A., \& Eccles, J.S. (2008). Parental influences on youth involvement in sports. In M.R. Weiss (Ed.), Developmental sport and exercise psychology: A lifespan perspective (pp. 145-164). Morgantown, WV: Fitness Information Technology.

Frick, P., \& Morris, A. S. (2004). Temperament and developmental pathways to severe conduct problems. Journal of Clinical Child and Adolescent Psychology, 33, 54-68. 
Frost, R., Marten, P., Lahart, C., \& Rosenblate, R. (1990). The dimensions of perfectionism. Cognitive Therapy and Research, 14, 449-468.

Gardner, M., Roth, J., \& Brooks-Gunn, J. (2009). Sport participation and juvenile delinquency: The role of the peer context among adolescent boys and girls with varied histories of problem behavior. Developmental Psychology, 45, 341-353.

Gaudreau, P., Amiot, C. E., \& Vallerand, R. J. (2009). Trajectories of affective states in adolescent hockey players: Turning point and motivational antecedents. Developmental Psychology, 45, 307-319.

Gaudreau, P., \& Blondin, J. (2002). Development of a questionnaire for the assessment of coping strategies employed by athletes in competitive sport settings. Psychology of Sport and Exercise, 3, 1-34.

Gaudreau, P., \& Blondin, J. (2004) Different athletes cope differently during a sport competition: a cluster analysis of coping. Personality and Individual Differences, 36, 1865-1877.

Gaudreau, P., Blondin, J.-P., \& Lapierre, A.-M. (2002). Athletes’ coping during a competition: relationship of coping strategies with positive affect, negative affect, and performancegoal discrepancy. Psychology of Sport and Exercise, 3, 125-150.

Gentzler, A. L., Contreras, J. M., Kerns, K. A., \& Weimer, B. L. (2005). Parent-child emotional communication and children’s coping in middle childhood. Social Development, 14, 591612.

Gilliom, M., Shaw, D., Beck, J., Schonberg, M., \& Lukon, J. (2002). Anger regulation in disadvantaged preschool boys: Strategies, antecedents, and the development of selfcontrol. Developmental Psychology, 38, 222-235. 
Gross, J. (1998). The emerging field of emotion regulation: An integrative review. Review of General Psychology, 2, 271-299.

Goldstein, J.D. \& Iso-Ahola, S.E. (2008). Determinants of parents’ “sideline rage” emotions and behaviors at youth soccer games. Journal of Applied Social Psychology, 38, 1442-1462.

Gore, S., Farrell, F., \& Gordon, J. (2001). Sports involvement as protection against depressed mood. Journal of Research on Adolescence, 11, 119- 130.

Gotwals, J. K., \& Dunn, J. G. H. (2009). A multi-method multi-analytic approach to establishing internal construct validity evidence: The Sport Multidimensional Perfectionism Scale 2. Measurement in Physical Education and Exercise Science, 13, 71-92.

Gould, D., \& Carson, S. (2004). Fun and games. Youth Studies Australia, 23, 19-26.

Gould, D., Eklund, R., Petlichkoff, L., Peterson, K., \& Bump, L. (1991). Psychological predictors of state anxiety and performance in age-group wrestlers. Pediatric Exercise Science, 3, 198-208.

Gould, D., Lauer, L., Rolo, C., Jannes, C., \& Pennisi, N. (2006). Understanding the role parents play in junior tennis success: A national survey of junior tennis coaches. British Journal of Sports Medicine, 40, 632-636.

Gould, D., Lauer, L., Rolo, C., Jannes, C., \& Pennisi, N. (2008). The role of parents in tennis success: Focus group interviews with junior coaches. The Sport Psychologist, 22, 18-37.

Gross, J.J. (1999). Emotion regulation: Past, present, future. Cognition and Emotion, 13, 551573.

Grossman, J. B. \& Rhodes, J. E. (2002). The test of time: Predictors and effects of duration in youth mentoring programs. American Journal of Community Psychology, 30, 199-206. 
Grove, R. J., \& Heard, P. N. (1997). Optimism and sport confidence as correlates of slumprelated coping among athletes. The Sport Psychologist, 11, 400-410.

Halberstadt, A. G., Denham, S. A., \& Dunsmore, J. C. (2001). Affective social competence. Social Development, 10, 79-119.

Hansen, D. M., Larson, R., \& Dworkin, J. (2003). What adolescents learn in organized youth activities: A survey of self-reported developmental experiences. Journal of Research on Adolescence, 13, 25-56.

Hardy, D. F., Power, T. G., \& Jaedicke, S. (1993). Examining the relation of parenting to children’s coping with everyday stress. Child Development, 64, 1829-1841.

Harter, S. (1978). The determinants and meditational role of self-esteem in children. In N. Eisenberg (Ed.), Contemporary topics in developmental psychology (pp. 219-242). New York: John Wiley \& Sons, Inc.

Harwood, C., \& Knight, C. (2009). Understanding parental stressors: An investigation of British tennis-parents. Journal of Sports Sciences, 27, 339-351.

Hellstedt, J. C. (1990). Early adolescent perceptions of parental pressure in the sport environment. Journal of Sport Behavior, 13, 135-144.

Holt, N. L., Tamminen, K. A., Black, D. E., Mandigo, J. L., \& Fox, K. R. (2009). Youth sport parenting styles and practices. Journal of Sport \& Exercise Psychology, 31(1), 37-59.

Hourigan, S. H., Goodman, K. L., \& Southam-Gerow, M. A. (2011). Discrepancies in parents' and children's reports of child emotion regulation. Journal of Experimental Child Psychology, 110, 198-212. 
Izard, C. E., Woodburn, E. M., Finlon, K. J., Krauthamer-Ewing, E. S., Grossman, S. R., \& Seidenfeld, A. (2011). Emotion knowledge, emotion utilization, and emotion regulation. Emotion Review, 3, 44-52.

Jones, R. L., Glintmeyer, N., \& McKenzie, A. (2005). Slim bodies, eating disorders and the coach-athlete relationship. International Review for the Sociology of Sport, 40, 377-391.

Kanters, M. A., Bocarro, J., \& Casper, J. (2008) Supported or pressured? An examination among parents and children on parent's role in youth sports. Journal of Sport Behavior, 31, 6480.

Kerr, D. C. R., Lunkenheimer, E. S., \& Olson, S. L. (2007). Assessment of child problem behavior by multiple informants: A longitudinal study from preschool to school entry. Journal of Child Psychology and Psychiatry, 48, 967-975.

Kirk, D. O'Connor, A., Carlson, T., Burke, P., Davis, K., \& Glover, S. (1997). Time commitments in junior sport: social consequences for participants and their families. European Journal of Physical Education, 2, 51-73.

Kliewer, W., Fearnow, M. D., \& Miller, P. A. (1996). Coping socialization in middle childhood: Tests of maternal and paternal influences. Child Development, 67, 2339-2357.

Knight, C. J., Boden, C. M., Holt, N. L. (2010). Junior tennis players’ preferences for parental behaviors. Journal of Applied Sport Psychology, 22, 377-391.

Lafferty, M. E., \& Dorrell, K. (2006). Coping strategies and the influence of perceived parental support in junior national age swimmers. Journal of Sports Sciences, 24, 253-259.

Larson, R. W. (2000). Toward a psychology of positive youth development. The American Psychologist, 55, 170-183. 
Larson, R. W., Hansen, D. M., \& Moneta, G. (2006). Differing profiles of developmental experiences across types of organized youth activities. Developmental Psychology, 42, 849-863.

Leff, S. S., \& Hoyle, R. H. (1995). Young athletes' perceptions of parental support and pressure. Journal of Youth and Adolescence, 24, 187-203.

Levine, L. J., Stein, N. L., \& Liwag, M. D. (1999). Remembering children’s emotions: Sources of concordant and discordant accounts between parents and children. Developmental Psychology, 35, 790-801.

Lewthwaite, R., \& Scanlan, T. K. (1989). Predictors of competitive trait anxiety in male youth sports participants. Medicine and Science in Sports and Exercise, 21, 221-229.

Mahoney, J. L., \& Cairns, R. B. (1997). Do extracurricular activities protect against early school dropout? Developmental Psychology, 33, 241-253.

Malecki, C. K., \& Demaray, M. K. (2002). Measuring perceived social support: Development of the child and adolescent social support scale. Psychology in the Schools, 39, 1-18.

McHale, S. M., Crouter, A. C., Tucker, C. J. (2001). Free-time activities in middle childhood: Links with adjustment in early adolescence. Child Development, 72, 1754-1778.

McLoyd, V. C. (1998). Socioeconomic disadvantage and child development. American Psychologist, 53, 185-204.

McNeal, R. B. (1995). Extracurricular activities and high school dropouts. Sociology of Education, 68, 62-81.

Morris, A. S., Silk, J. S., Steinberg, L., Myers, S. S., \& Robinson, L. R. (2007). The role of the family context in the development of emotional regulation. Social Development, 16, 361388. 
Murphy, S. (1999). The cheers and the tears: A healthy alternative to the dark side of youth sports today. San Francisco, CA: Jossey-Bass.

National Center for Public Policy and Higher Education. (2008). Measuring up 2008: The national report card on higher education. Retrieved February 27, 2010, from http://measuringup2008.highereducation.org/print/NCPPHEMUNationalRpt.pdf

National Federation of State High School Associations. (2009). 2008-09 State High School Athletics Participation Survey. Indianapolis, IN: Author. Retrieved February 8, 2010, from: http://www.nfhs.org/WorkArea/linkit.aspx?LinkIdentifier=id\&ItemID=3506

Nicholls, J.G. (1989). The competitive ethos and democratic education. Cambridge: Harvard University Press.

Omli, J., \& LaVoi, N. M. (2009). Background anger in youth sport: A perfect storm? Journal of Sport Behavior, 32, 242-260.

Parke, R. D. (1994). Progress, paradigms, and unresolved problems: A commentary on recent advances in our understanding of children's emotions. Merrill-Palmer Quarterly, 40, $157-169$.

Petitpas, A. J., Cornelius, A. E., Van Raalte, J. L., \& Jones, T. (2005). A framework for planning youth sport programs that foster psychosocial development. Sport Psychologist, 19, 6380.

Phillips, K. F. V., \& Power, M. J. (2007). A new self-report measure of emotion regulation in adolescents: The regulation of emotions questionnaire. Clinical Psychology and Psychotherapy, 14, 145-156.

Posner, J. K., \& Vandall, D. L. (1999). After-school activities and the development of lowincome urban children: A longitudinal study. Developmental Psychology, 35, 868-879. 
Ryan, E. L., \& Deci, R. M. (2000). Self-determination theory and the facilitation of intrinsic motivation, social development, and wellbeing. The American Psychologist, 55, 68-78.

Sagar, S. S., Lavallee, D. (2010). The developmental origins of fear of failure in adolescent athletes: Examining parental practices. Psychology of Sport and Exercise, 11, 177-187.

Scanlan, T. K. (2002). Social evaluation and the competition process: A developmental perspective. In F. L. Smoll \& R. E. Smith (Eds.), Children and youth in sport: A biopsychosocial perspective (2nd ed., pp. 393-407). Dubuque, IA: Kendall/Hunt.

Scanlan, T., Babkes, M., \& Scanlan, L. (2005). Participation in sport: A developmental glimpse at emotion. In J. Mahoney, J. Eccles, \& R. Larson (Eds.), Organized activities as contexts of development (pp. 275-309). Mahwah, NJ: Erlbaum.

Scanlan, T. K., \& Lewthwaite, R. (1984). Social psychological aspects of competition for male youth sport participants I: Predictors of competitive stress. Journal of Sport Psychology, 6, 208-226.

Shields, D. L. L., \& Bredemeier, B. J. L. (1995). Character development and physical activity. Champaign, IL: Human Kinetics.

Shipman, K. L., Zeman, J., Nesin, A. E., Fitzgerald, M. (2003). Children’s strategies for displaying anger and sadness: What works with whom? Merill-Palmer Quarterly, 49, 100-122.

Silk, J. S., Steinberg, L., \& Morris, A. S. (2003). Adolescents’ emotion regulation in daily life: Links to depressive symptoms and problem behavior. Child Development, 74, 1869_ 1880.

Skinner, E. A., \& Zimmer-Gembeck, M. J. (2007). The development of coping. Annual Review of Psychology, 58, 119-144. 
Smith, N. J., Smith, R. E., \& Smoll, F. L. (1985). Kidsports: A survival guide for parents. Reading, MA: Addison-Wesley.

Smoll, F., \& Smith, R. (1996). Children and youth in sport: A biopsychosocial perspective. Chicago: Brown \& Benchmark.

Thompson, R. A. (1994). Emotion regulation: A theme in search of definition. In N. A. Fox (Ed.), The development of emotion regulation: Biological and behavioral considerations. Monographs of the Society for Research in Child Development, 59(2-3, Serial No. 240), 25-52.

Tofler, I. R., Knapp, P. K., \& Drell, M. J. (1998). The achievement by proxy spectrum in youth sports. Child and Adolescent Psychiatric Clinics of North America, 7, 803-820.

Tofler, I. R., Knapp, P. K., \& Drell, M. J. (1999). The “achievement by proxy” spectrum: Recognition and clinical response to pressured and high-achieving children and adolescents. Journal of the American Academy of Child and Adolescent Psychiatry, 38, $213-216$.

Vallerand, R. J., Blanchard, C., Mageau, G. A., Koestner, R., Ratelle, C., Leonard, M. ... Marsolais, J. (2003). Les passions de l'ame: On obsessive and harmonious passion. Journal of Personality and Social Psychology, 85, 756-767.

VanYperen, N. W. (1995). Interpersonal stress, performance level, and parental support: A longitudinal study among highly skilled young soccer players. The Sport Psychologist, 9, $225-241$.

Zeman, J. L., Cassano, M., Suveg, C., \& Shipman, K. (2010). Initial validation of the children’s worry management scale. Journal of Child and Family Studies. DOI: 10.1007/s10826009-9308-4. 
Zenam, J. L., \& Garber, J. (1996). Display rules for anger, sadness, and pain: It depends on who is watching. Child Development, 67, 957-973.

Zeman, J., Shipman, K., \& Penza-Clyve, S. (2001). Development and initial validation of the Children’s Sadness Management Scale. Journal of Nonverbal Behavior, 25, 187-205.

Zeman, J., Shipman, K., \& Suveg, C. (2002). Anger and sadness regulation: Predictions to internalizing and externalizing symptoms in children. Journal of Clinical Child and Adolescent Psychology, 31, 393-398. 
Table 1

Means, Standard Deviations, and Bivariate Correlations for Support, Pressure, and Emotion Regulation

\begin{tabular}{|c|c|c|c|c|c|c|c|c|c|c|}
\hline & $\begin{array}{c}M \\
(S D) \\
\end{array}$ & 2 & 3 & 4 & 5 & 6 & 7 & 8 & 9 & 10 \\
\hline $\begin{array}{l}\text { 1. Pressure } \\
\text { (General) }\end{array}$ & $22.06(7.16)$ & $-.41 * * *$ & $.67 * * *$ & $-.37 * *$ & .04 & .02 & -.21 & $.38^{* *}$ & -.21 & .13 \\
\hline $\begin{array}{l}\text { 2. Support } \\
\text { (General) }\end{array}$ & 79.09 (10.84) & & $-.34 * *$ & $.69 * * *$ & .04 & -.11 & $.30 * *$ & -.11 & .16 & $-.25 *$ \\
\hline $\begin{array}{l}\text { 3. Pressure } \\
\text { (Soccer) }\end{array}$ & $22.67(7.00)$ & & & -.19 & .15 & -.13 & -.12 & $.25 *$ & $-.24 *$ & .14 \\
\hline $\begin{array}{l}\text { 4. Support } \\
\text { (Soccer) }\end{array}$ & 79.69 (12.21) & & & & .05 & .01 & .06 & .05 & .21 & -.04 \\
\hline 5. Anger Coping & $9.33(1.68)$ & & & & & $-.27 *$ & $.33^{* *}$ & -.13 & .16 & -.07 \\
\hline $\begin{array}{l}\text { 6. Anger } \\
\text { Dysregulation }\end{array}$ & 4.48 (1.33) & & & & & & $-.23 *$ & $.26^{*}$ & -.10 & $.25^{*}$ \\
\hline $\begin{array}{l}\text { 7. Sadness } \\
\text { Coping }\end{array}$ & $9.49(1.64)$ & & & & & & & $-.36 * *$ & $.39 * * *$ & -.16 \\
\hline $\begin{array}{l}\text { 8. Sadness } \\
\text { Dysregulation }\end{array}$ & $2.94(1.01)$ & & & & & & & & -.14 & $.25 *$ \\
\hline 9. Worry Coping & $4.73(1.09)$ & & & & & & & & & $-.44 * * *$ \\
\hline $\begin{array}{l}\text { 10. Worry } \\
\text { Dysegulation }\end{array}$ & $4.02(1.32)$ & & & & & & & & & \\
\hline
\end{tabular}

Note. ${ }^{*} p<.05,{ }^{* *} p<.01, * * * p<.001$ 
Table 2

Perceived Soccer-Related Parent Support and Pressure Predicting Children's Anger Regulation

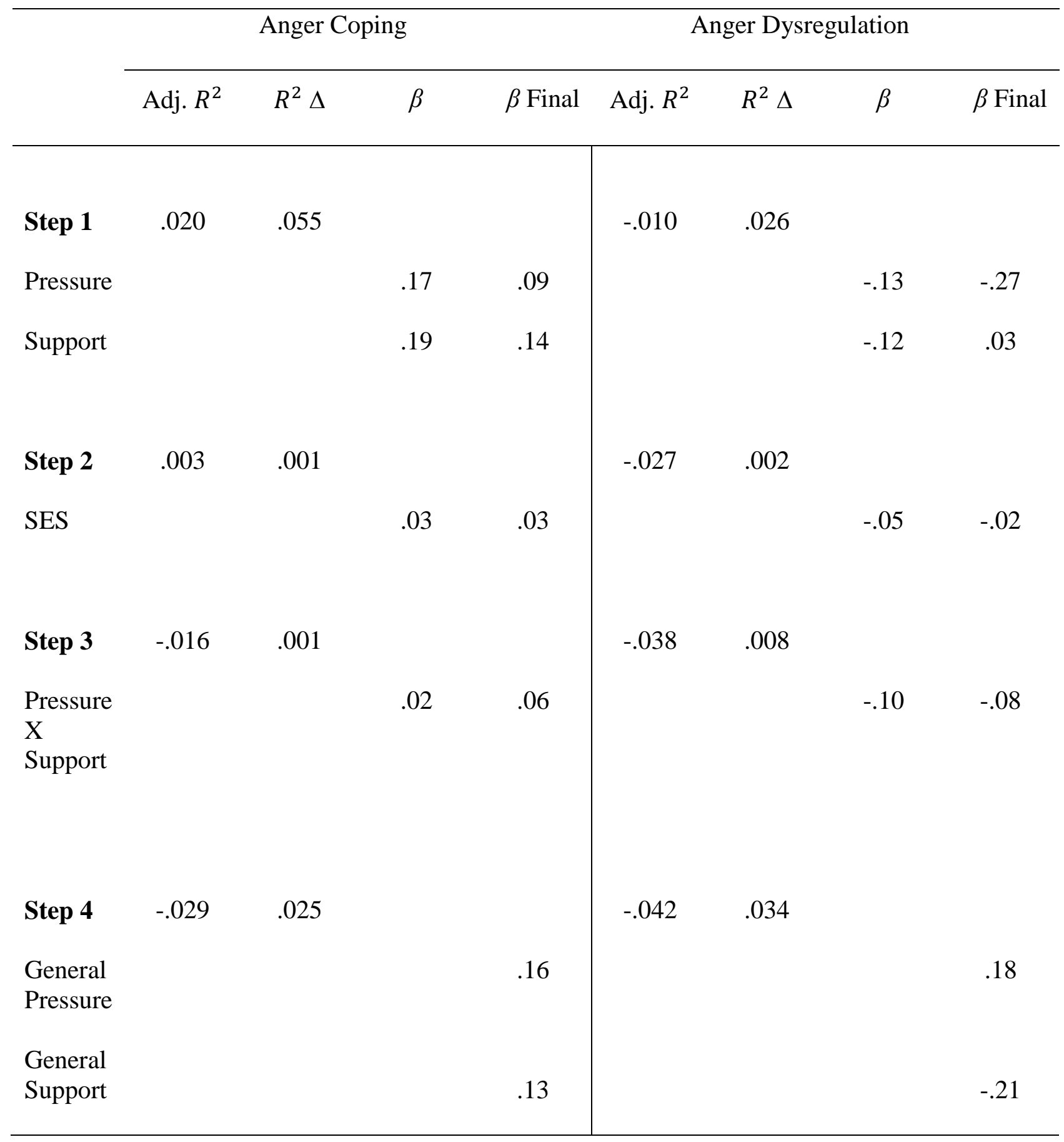


Table 3

Perceived Soccer-Related Parent Support and Pressure Predicting Children's Sadness Regulation

$$
\text { Sadness Coping Sadness Dysregulation }
$$

$\begin{array}{llllllll}\text { Adj. } R^{2} & R^{2} \Delta & \beta & \beta \text { Final } & \text { Adj. } R^{2} & R^{2} \Delta & \beta & \beta \text { Final }\end{array}$

\begin{tabular}{|c|c|c|c|c|c|c|c|c|}
\hline Step 1 & -.02 & .02 & & & .07 & $.10++$ & & \\
\hline Pressure & & & .03 & .16 & & & $.26+$ & -.10 \\
\hline Support & & & .13 & -.24 & & & -.15 & .08 \\
\hline Step 2 & -.02 & .02 & & & .05 & .00 & & \\
\hline SES & & & -.16 & -.22 & & & -.06 & .01 \\
\hline Step 3 & -.04 & .00 & & & .03 & .003 & & \\
\hline $\begin{array}{l}\text { Pressure } \\
\text { X } \\
\text { Support }\end{array}$ & & & .01 & .02 & & & .01 & .07 \\
\hline Step 4 & .07 & $.13^{*}$ & & & .13 & $.12 *$ & & \\
\hline $\begin{array}{l}\text { General } \\
\text { Pressure }\end{array}$ & & & & -.20 & & & & $.48 *$ \\
\hline $\begin{array}{l}\text { General } \\
\text { Support }\end{array}$ & & & & $.48 * *$ & & & & -.26 \\
\hline
\end{tabular}

Note. ${ }^{++} \mathrm{p}=.06,+p=.05 * p<.05, * * p<.01$. 
Table 4

Perceived Soccer-Related Parent Support and Pressure Predicting Children's Worry Regulation

\begin{tabular}{|c|c|c|c|c|c|c|c|c|}
\hline & \multicolumn{4}{|c|}{ Worry Coping } & \multicolumn{4}{|c|}{ Worry Dysregulation } \\
\hline & Adj. $R^{2}$ & $R^{2} \Delta$ & $\beta$ & $\beta$ Final & Adj. $R^{2}$ & $R^{2} \Delta$ & $\beta$ & $\beta$ Final \\
\hline Step 1 & .09 & $.12^{*}$ & & & .01 & .05 & & \\
\hline Pressure & & & $-.28 *$ & $-.37+$ & & & .21 & .18 \\
\hline Support & & & .17 & .15 & & & .08 & $.40^{*}$ \\
\hline Step 2 & .09 & .012 & & & .03 & .03 & & \\
\hline SES & & & -.12 & -.10 & & & .19 & $.25++$ \\
\hline Step 3 & .15 & $.071^{*}$ & & & .01 & .005 & & \\
\hline $\begin{array}{l}\text { Pressure } \\
\text { X } \\
\text { Support }\end{array}$ & & & $.28 *$ & $.29 *$ & & & .08 & .06 \\
\hline Step 4 & .12 & .003 & & & .07 & $.08 \#$ & & \\
\hline $\begin{array}{l}\text { General } \\
\text { Pressure }\end{array}$ & & & & -.003 & & & & .06 \\
\hline $\begin{array}{l}\text { General } \\
\text { Support }\end{array}$ & & & & .08 & & & & $-.40 *$ \\
\hline
\end{tabular}

Note. $\# p=.09,++p=.08,+p=.05,{ }^{*} p<.05$. 
Figure 1. Interaction between Pressure and Support Predicting Children’s Coping with Worry

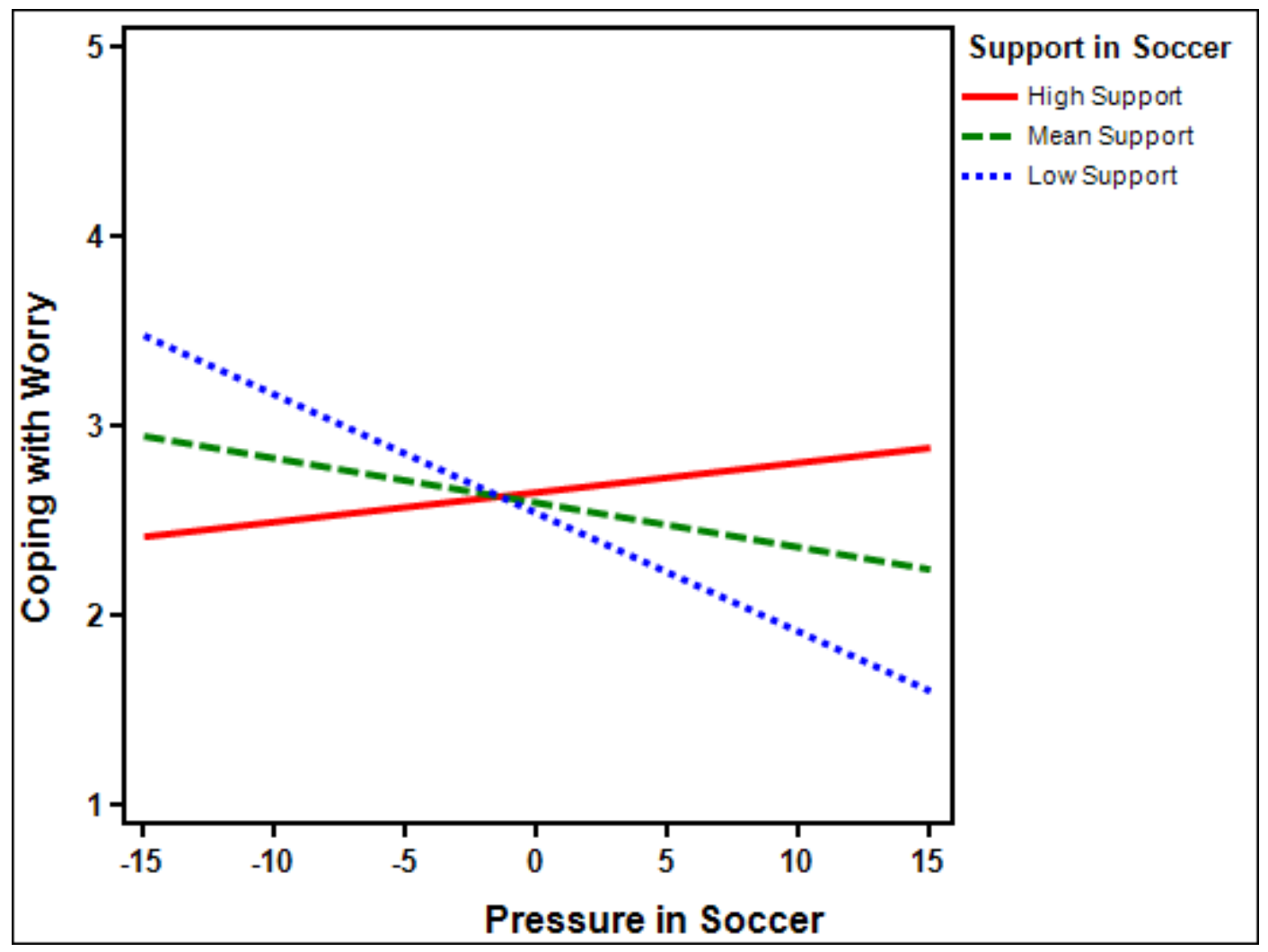

Note. High and low levels of support are presented as +1 and -1 standard deviation from the mean. Values displayed for pressure in soccer are centered around the mean. 


\section{Appendix A}

\section{Demographics and Soccer Involvement - Parent}

Today's Date:

Time you are filling this form out: AM PM (circle one)

What team is your child playing with in this tournament?

What age group? U-

Where do you live?

City: State:

Is this city urban, suburban, or rural? (Please circle one)

What is your relationship to the child participating in the study?

a. Biological mother

b. Biological father

c. Stepmother

d. Stepfather

e. Other

Are there any other people that play a parenting role in this child's life? (Examples: spouse, ex-spouse, stepmom, stepdad, live-in significant other)?

Is this person or are these people currently living with the child?

If yes, is this person or are these people living with the child part-time or full-time?

Is this person or are these people also involved in the child's sport participation?

What is your child's birth date (MM/DD/YYYY)?

What is your child's sex?

What is your child's race? (Circle all that apply)

a. White/Caucasian

b. Black/African-American

c. Asian or Pacific Islander

d. Latino or Hispanic

e. American Indian, Eskimo, or Aleut

f. Other

Does your child have any siblings? (Please circle)

Yes No

If yes, please list the age and gender for each. 
Do any of these siblings play sports? (Please indicate which sibling/s and which sports)

Are any of these siblings also participating in the study? (If yes, please include the ID number listed on the study packet given to the sibling)

How long has your child been involved in sports? years

How long has your child been involved in soccer? years

Does your child currently play any other sports? If yes, please list each one(s).

If the child does play other sports, which sport are they most involved in? (Please circle one)

Soccer Other:

On a scale of 1-7, with 1 being very difficult and 7 being not difficult at all, how hard is it for you to pay your monthly bills? (Please circle one)

1-----2-----3------4-----5-----6-----7

Please answer the following questions about the child participating in the study with you.

How much money do you currently spend on your child's soccer each year? \$

On a scale of 1-7, with 1 being very difficult and 7 being not difficult at all, how hard is it for you to afford your child's soccer? (Please circle one)

1-----2-----3------4-----5------6-----7

On average, how much time do you spend each week on your child's soccer (driving, at practices, games, meetings, etc.)? hours

On a scale from 1-7, with 1 being very difficult and 7 being not difficult at all, how hard is it for you to find the time for your child's soccer? (Please circle one)

1-----2-----3------4-----5------6-----7

On a scale of 1-7, from 1 being the best and 7 being the worst, how would you rate your child's playing ability compared to the other players on this team? (Please circle one)

1-----2-----3------4-----5-----6-----7

On a scale of 1-7, from 1 being very important and 7 being not important at all, how important would you say that soccer is for your child? (Please circle one)

1-----2-----3------4-----5-----6-----7 


\section{Appendix B}

\section{Demographics and Soccer Involvement - Child}

Today's Date:

Time you are filling this form out: AM PM (circle one)

On a scale of 1-7, with 1 being very difficult and 7 being not difficult at all, how hard is it for your parents to pay for your soccer? (Please circle one)

1-----2-----3------4-----5------6-----7

On a scale from 1-7, with 1 being very difficult and 7 being not difficult at all, how hard is it for your parents to find the time for your soccer? (Please circle one)

1-----2-----3------4-----5------6-----7

On a scale of 1-7, from 1 being the best and 7 being the worst, how would you rate your playing ability compared to the other players on the team? (Please circle one)

1-----2-----3------4-----5------6-----7

On a scale of 1-7, from 1 being very important and 7 being not important at all, how important would you say that soccer is for you? (Please circle one)

1-----2-----3-----4-----5-----6-----7

On a scale of 1-7, from 1 being very enjoyable and 7 being not enjoyable at all, how enjoyable would you say that soccer is for you? (Please circle one)

1-----2------3------4-----5------6-----7 


\section{Appendix C}

\section{Children's Emotion Management Scale: Anger}

For these next questions, please circle the response that best describes your behavior when you are feeling mad.

\begin{tabular}{|c|c|c|c|c|}
\hline & When I'm feeling mad, I control my temper. & $\begin{array}{c}\text { Hardly Ever } \\
1\end{array}$ & $\begin{array}{c}\text { Sometimes } \\
2\end{array}$ & $\begin{array}{c}\text { Often } \\
3\end{array}$ \\
\hline 2. & I hold my anger in. & $\begin{array}{c}\text { Hardly Ever } \\
1\end{array}$ & $\begin{array}{c}\text { Sometimes } \\
2\end{array}$ & $\begin{array}{c}\text { Often } \\
3\end{array}$ \\
\hline 3. & I stay calm and keep my cool when I am feeling mad. & $\begin{array}{c}\text { Hardly Ever } \\
1\end{array}$ & $\begin{array}{c}\text { Sometimes } \\
2\end{array}$ & $\begin{array}{c}\text { Often } \\
3\end{array}$ \\
\hline 4. & I do things like slam doors when I am mad & $\begin{array}{c}\text { Hardly Ever } \\
1\end{array}$ & $\begin{array}{c}\text { Sometimes } \\
2\end{array}$ & $\begin{array}{c}\text { Often } \\
3\end{array}$ \\
\hline 5. & I hide my anger. & $\begin{array}{c}\text { Hardly Ever } \\
1\end{array}$ & $\begin{array}{c}\text { Sometimes } \\
2 \\
\end{array}$ & $\begin{array}{c}\text { Often } \\
3\end{array}$ \\
\hline 6. & I attack whatever it is that makes me mad. & $\begin{array}{c}\text { Hardly Ever } \\
1 \\
\end{array}$ & $\begin{array}{c}\text { Sometimes } \\
2 \\
\end{array}$ & $\begin{array}{c}\text { Often } \\
3\end{array}$ \\
\hline 7. & I get mad inside but don't show it. & $\begin{array}{c}\text { Hardly Ever } \\
1\end{array}$ & $\begin{array}{c}\text { Sometimes } \\
2\end{array}$ & $\begin{array}{c}\text { Often } \\
3\end{array}$ \\
\hline 8. & I can stop myself from losing my temper. & $\begin{array}{c}\text { Hardly Ever } \\
1 \\
\end{array}$ & $\begin{array}{c}\text { Sometimes } \\
2 \\
\end{array}$ & $\begin{array}{c}\text { Often } \\
3\end{array}$ \\
\hline 9. & I say mean things to others when I am mad. & $\begin{array}{c}\text { Hardly Ever } \\
1 \\
\end{array}$ & $\begin{array}{c}\text { Sometimes } \\
2 \\
\end{array}$ & $\begin{array}{c}\text { Often } \\
3 \\
\end{array}$ \\
\hline 10. & I try to calmly deal with what is making me feel mad. & $\begin{array}{c}\text { Hardly Ever } \\
1\end{array}$ & $\begin{array}{c}\text { Sometimes } \\
2 \\
\end{array}$ & $\begin{array}{c}\text { Often } \\
3\end{array}$ \\
\hline & I'm afraid to show my anger. & $\begin{array}{c}\text { Hardly Ever } \\
1\end{array}$ & $\begin{array}{c}\text { Sometimes } \\
2\end{array}$ & $\begin{array}{c}\text { Often } \\
3\end{array}$ \\
\hline
\end{tabular}




\section{Appendix D}

\section{Children's Emotion Management Scale: Sadness}

Please circle the response that best describes your behavior when you are feeling sad.

\begin{tabular}{|c|c|c|c|c|}
\hline 1. & When I'm feeling sad, I can control my crying and carrying on. & $\begin{array}{c}\text { Hardly Ever } \\
1\end{array}$ & $\begin{array}{c}\text { Sometimes } \\
2\end{array}$ & $\begin{array}{c}\text { Often } \\
3\end{array}$ \\
\hline 2. & I hold my sad feelings in. & $\begin{array}{c}\text { Hardly Ever } \\
1\end{array}$ & $\begin{array}{c}\text { Sometimes } \\
2\end{array}$ & $\begin{array}{c}\text { Often } \\
3\end{array}$ \\
\hline 3. & I stay calm and don't let sad things get to me. & $\begin{array}{c}\text { Hardly Ever } \\
1\end{array}$ & $\begin{array}{c}\text { Sometimes } \\
2\end{array}$ & $\begin{array}{c}\text { Often } \\
3\end{array}$ \\
\hline 4. & I whine/fuss about what's making me sad. & $\begin{array}{c}\text { Hardly Ever } \\
1\end{array}$ & $\begin{array}{c}\text { Sometimes } \\
2\end{array}$ & $\begin{array}{c}\text { Often } \\
3\end{array}$ \\
\hline 5. & I hide my sadness. & $\begin{array}{c}\text { Hardly Ever } \\
1\end{array}$ & $\begin{array}{c}\text { Sometimes } \\
2\end{array}$ & $\begin{array}{c}\text { Often } \\
3\end{array}$ \\
\hline 6. & When I'm sad, I do something totally different until I calm down. & $\begin{array}{c}\text { Hardly Ever } \\
1\end{array}$ & $\begin{array}{c}\text { Sometimes } \\
2\end{array}$ & $\begin{array}{c}\text { Often } \\
3\end{array}$ \\
\hline 7. & I get sad inside but don't show it. & $\begin{array}{c}\text { Hardly Ever } \\
1\end{array}$ & $\begin{array}{c}\text { Sometimes } \\
2\end{array}$ & $\begin{array}{c}\text { Often } \\
3\end{array}$ \\
\hline 8. & I can stop myself from losing control of my sad feelings. & $\begin{array}{c}\text { Hardly Ever } \\
1 \\
\end{array}$ & $\begin{array}{c}\text { Sometimes } \\
2 \\
\end{array}$ & $\begin{array}{c}\text { Often } \\
3 \\
\end{array}$ \\
\hline 9. & I cry and carry on when I'm sad. & $\begin{array}{c}\text { Hardly Ever } \\
1 \\
\end{array}$ & $\begin{array}{c}\text { Sometimes } \\
2 \\
\end{array}$ & $\begin{array}{c}\text { Often } \\
3 \\
\end{array}$ \\
\hline 10. & I try to calmly deal with what is making me sad. & $\begin{array}{c}\text { Hardly Ever } \\
1\end{array}$ & $\begin{array}{c}\text { Sometimes } \\
2\end{array}$ & $\begin{array}{c}\text { Often } \\
3\end{array}$ \\
\hline 11. & I do things like mope around when I'm sad. & $\begin{array}{c}\text { Hardly Ever } \\
1\end{array}$ & $\begin{array}{c}\text { Sometimes } \\
2\end{array}$ & $\begin{array}{c}\text { Often } \\
3\end{array}$ \\
\hline 12. I & n afraid to show my sadness. & $\begin{array}{c}\text { Hardly Ever } \\
1\end{array}$ & $\begin{array}{c}\text { Sometimes } \\
2\end{array}$ & $\begin{array}{c}\text { Often } \\
3\end{array}$ \\
\hline
\end{tabular}




\section{Appendix E}

\section{Children's Emotion Management Scale: Worry}

Please circle the response that best describes your behavior when you are feeling worried.

\begin{tabular}{|c|c|c|c|c|}
\hline 1. & I keep myself from losing control of my worried feelings. & $\begin{array}{c}\text { Hardly Ever } \\
1 \\
\end{array}$ & $\begin{array}{c}\text { Sometimes } \\
2 \\
\end{array}$ & $\begin{array}{c}\text { Often } \\
3 \\
\end{array}$ \\
\hline 2. & I show my worried feelings. & $\begin{array}{c}\text { Hardly Ever } \\
1\end{array}$ & $\begin{array}{c}\text { Sometimes } \\
2\end{array}$ & $\begin{array}{c}\text { Often } \\
3\end{array}$ \\
\hline 3. & I hold my worried feelings in. & $\begin{array}{c}\text { Hardly Ever } \\
1\end{array}$ & $\begin{array}{c}\text { Sometimes } \\
2\end{array}$ & $\begin{array}{c}\text { Often } \\
3\end{array}$ \\
\hline 4. & I talk to someone until I feel better when I'm worried. & $\begin{array}{c}\text { Hardly Ever } \\
1 \\
\end{array}$ & $\begin{array}{c}\text { Sometimes } \\
2 \\
\end{array}$ & $\begin{array}{c}\text { Often } \\
3 \\
\end{array}$ \\
\hline 5. & I do things like cry and carry on when I'm worried. & $\begin{array}{c}\text { Hardly Ever } \\
1 \\
\end{array}$ & $\begin{array}{c}\text { Sometimes } \\
2 \\
\end{array}$ & $\begin{array}{c}\text { Often } \\
3 \\
\end{array}$ \\
\hline 6. & I hide my worried feelings. & $\begin{array}{c}\text { Hardly Ever } \\
1 \\
\end{array}$ & $\begin{array}{c}\text { Sometimes } \\
2 \\
\end{array}$ & $\begin{array}{c}\text { Often } \\
3 \\
\end{array}$ \\
\hline 7. & I keep whining about how worried I am. & $\begin{array}{c}\text { Hardly Ever } \\
1\end{array}$ & $\begin{array}{c}\text { Sometimes } \\
2\end{array}$ & $\begin{array}{c}\text { Often } \\
3\end{array}$ \\
\hline 8. & I get worried inside but don't show it. & $\begin{array}{c}\text { Hardly Ever } \\
1 \\
\end{array}$ & $\begin{array}{c}\text { Sometimes } \\
2 \\
\end{array}$ & $\begin{array}{c}\text { Often } \\
3 \\
\end{array}$ \\
\hline 9. & I can't stop myself from acting really worried. & $\begin{array}{c}\text { Hardly Ever } \\
1 \\
\end{array}$ & $\begin{array}{c}\text { Sometimes } \\
2 \\
\end{array}$ & $\begin{array}{c}\text { Often } \\
3 \\
\end{array}$ \\
\hline & I try to calmly settle the problem when I feel worried. & $\begin{array}{c}\text { Hardly Ever } \\
1\end{array}$ & $\begin{array}{c}\text { Sometimes } \\
2\end{array}$ & $\begin{array}{c}\text { Often } \\
3\end{array}$ \\
\hline
\end{tabular}




\section{Appendix F}

\section{Sport - Multidimensional Perfectionism Scale (MPS)-2}

Please help us to more fully understand how players view a variety of their competitive experiences by indicating the extent to which you agree or disagree with the following statements. (Circle one response option to the right of each statement). There are no right or wrong answers so please don't spend too much time on any one statement; simply choose the answer that best describes how you view each statement. Please answer these questions for the parent who is participating in this study with you.

\begin{tabular}{|c|c|c|c|c|c|}
\hline $\begin{array}{l}\text { To what extent do you agree or disagree with the } \\
\text { following statements? }\end{array}$ & $\begin{array}{l}\text { Strongly } \\
\text { Disagree }\end{array}$ & Disagree & $\begin{array}{l}\text { Neither } \\
\text { Agree or } \\
\text { Disagree }\end{array}$ & Agree & $\begin{array}{l}\text { Strongly } \\
\text { Agree }\end{array}$ \\
\hline $\begin{array}{l}\text { 1. My parent sets very high standards for me in } \\
\text { soccer. }\end{array}$ & 1 & 2 & 3 & 4 & 5 \\
\hline $\begin{array}{l}\text { 2. In soccer, I never feel like I can quite meet my } \\
\text { parent's expectations. }\end{array}$ & 1 & 2 & 3 & 4 & 5 \\
\hline $\begin{array}{l}\text { 3. Only outstanding performance during soccer is } \\
\text { good enough for my parent. }\end{array}$ & 1 & 2 & 3 & 4 & 5 \\
\hline $\begin{array}{l}\text { 4. My parent has always had higher expectations for } \\
\text { my future in soccer than I have. }\end{array}$ & 1 & 2 & 3 & 4 & 5 \\
\hline $\begin{array}{l}\text { 5. I feel like I am criticized by my parent for doing } \\
\text { things less than perfectly in soccer. }\end{array}$ & 1 & 2 & 3 & 4 & 5 \\
\hline $\begin{array}{l}\text { 6. In soccer, I never feel like I can quite live up to my } \\
\text { parent's standards. }\end{array}$ & 1 & 2 & 3 & 4 & 5 \\
\hline 7. My parent expects excellence from me in soccer. & 1 & 2 & 3 & 4 & 5 \\
\hline $\begin{array}{l}\text { 8. I feel like my parent never tries to fully } \\
\text { understand the mistakes I make in soccer. }\end{array}$ & 1 & 2 & 3 & 4 & 5 \\
\hline $\begin{array}{l}\text { 9. My parent wants me to be better than all other } \\
\text { players who play soccer. }\end{array}$ & 1 & 2 & 3 & 4 & 5 \\
\hline
\end{tabular}




\section{Appendix G}

\section{Multidimensional Perfectionism Scale (MPS)}

Please think about your parent and how they are in general. Please answer these questions for the parent who is participating in this study with you. Please circle the number that best describes your agreement with each statement below.

Use this rating system: Strongly disagree 12345 Strongly agree

Strongly Disagree.....Strongly Agree

1. My parent sets very high standards for me.

$\begin{array}{lllll}1 & 2 & 3 & 4 & 5\end{array}$

2. I am punished for doing thing less than perfectly.

$\begin{array}{lllll}1 & 2 & 3 & 4 & 5\end{array}$

3. My parent never tries to understand my mistakes.

$\begin{array}{lllll}1 & 2 & 3 & 4 & 5\end{array}$

4. My parent wants me to be the best at everything.

$\begin{array}{lllll}1 & 2 & 3 & 4 & 5\end{array}$

5. Only outstanding performance is good enough

$\begin{array}{lllll}1 & 2 & 3 & 4 & 5\end{array}$

for my parent.

6. My parent expects excellence from me.

$\begin{array}{lllll}1 & 2 & 3 & 4 & 5\end{array}$

7. I never feel like I can meet my parent's expectations.

$\begin{array}{lllll}1 & 2 & 3 & 4 & 5\end{array}$

8. My parent always has higher expectations for my

$\begin{array}{lllll}1 & 2 & 3 & 4 & 5\end{array}$

future than I have.

9. I never feel like I can meet my parent's standards.

$\begin{array}{lllll}1 & 2 & 3 & 4 & 5\end{array}$ 


\section{Appendix H}

\section{CHILD AND ADOLESCENT SOCIAL SUPPORT SCALE (CASSS)}

On this page, you will be asked to respond to sentences about some form of support or help that you might get from your parent. Please answer these questions for the parent who is participating in this study with you. Read each sentence carefully and respond to them honestly. There are no right or wrong answers.

For each sentence you are asked to provide two responses. First, rate how often you receive the support described and then rate how important the support is to you. Below is an example. Please read it carefully before starting your own ratings.

In this example, the student describes her 'teacher helps me solve problems' as something that happens 'some of the time' and that is 'important' to her.

\begin{tabular}{|c|c|c|c|c|c|c|c|c|c|}
\hline \multirow{3}{*}{$\begin{array}{l}\text { My } \\
\text { parent } \\
\text { helps me } \\
\text { solve } \\
\text { problems }\end{array}$} & \multicolumn{6}{|c|}{ HOW OFTEN? } & \multicolumn{3}{|c|}{ IMPORTANT? } \\
\hline & NEVER & $\begin{array}{c}\text { ALMOST } \\
\text { NEVER }\end{array}$ & $\begin{array}{l}\text { SOME OF } \\
\text { THE TIME }\end{array}$ & $\begin{array}{l}\text { MOST OF } \\
\text { THE TIME }\end{array}$ & $\begin{array}{l}\text { ALMOST } \\
\text { ALWAYS }\end{array}$ & ALWAYS & $\begin{array}{c}\text { NOT } \\
\text { IMPORTANT }\end{array}$ & IMPORTANT & $\begin{array}{c}\text { VERY } \\
\text { IMPORTANT }\end{array}$ \\
\hline & 1 & 2 & 3 & 4 & 5 & 6 & 1 & $(2$ & 3 \\
\hline
\end{tabular}

Please ask for help if you have a question or don't understand something. Do not skip any sentences.

$$
\text { Thank you! }
$$

My Parent....

1....shows that they are proud of me.

2. ...understands me.

3. ...listens to me when I need to talk.

4. ...makes suggestions when I don't know what to do.

5. ...gives me good advice.

6. ...helps me solve problems by giving me information.

7. ...tells me I did a good job when I do something well.

8. ...nicely tells me when I make mistakes.

9. ...rewards me when I've done something well.

10. ...helps me practice my activities.

11. ...takes time to help me decide things.

12. ...gets me many of the things I need.

13. ...makes me feel like it's okay to make mistakes.

14. ... loves me even if I fail.

15. ...helps me feel better after I make a mistake.

16. ...lets me know that it's okay to not be the best.
HOW OFTEN? IMPORTANT?
123456
123
123456
123
123456
123
123456
123
123456
123
123456
123
123456
123
123456
123
123456
123
123456
123
123456
123
123456
123
123456
123
123456
123
123456
123
$123456 \quad 123$ 


\section{Appendix I}

\section{CHILD AND ADOLESCENT SOCIAL SUPPORT SCALE (CASSS) - Sport Version}

In this section, you will be asked to answer questions about your parent and how they are with soccer. Please answer these questions for the parent who is participating in this study with you.

\begin{tabular}{|c|c|c|c|c|c|c|c|c|}
\hline \multicolumn{6}{|c|}{ HOW OFTEN? } & \multicolumn{3}{|c|}{ IMPORTANT? } \\
\hline NEVER & $\begin{array}{l}\text { ALMOST } \\
\text { NEVER }\end{array}$ & $\begin{array}{l}\text { SOME OF } \\
\text { THE TIME }\end{array}$ & $\begin{array}{l}\text { MOST OF } \\
\text { THE TIME }\end{array}$ & $\begin{array}{l}\text { ALMOST } \\
\text { ALWAYS }\end{array}$ & ALWAYS & $\begin{array}{c}\text { NOT } \\
\text { IMPORTANT }\end{array}$ & IMPORTANT & $\begin{array}{c}\text { VERY } \\
\text { IMPORTANT }\end{array}$ \\
\hline 1 & 2 & 3 & 4 & 5 & 6 & 1 & 2 & 3 \\
\hline
\end{tabular}

My Parent....

1. ...shows that they are proud of me and my soccer.

2. ...understands me when it comes to things related to soccer.

3. ...listens to me when I need to talk about soccer.

4. ...makes suggestions when I don't know what to do about something related to soccer.

5...gives me good advice about soccer.

6....helps me solve problems related to soccer by giving me information.

7. ...tells me I did a good job when I do something well in soccer.

8. ...nicely tells me when I make mistakes in soccer.

9. ...rewards me when l've done something well in soccer.

10. ...helps me practice my soccer.

11. ...takes time to help me decide things related to soccer.

12. ...gets me many of the things I need for soccer.

13. ...makes me feel like it's okay to make mistakes in soccer.

14. ...loves me even if I fail in soccer.

15. ...helps me feel better after I make a mistake in soccer.

16. ... lets me know that it's okay to not be the best in soccer.
HOW OFTEN? IMPORTANT?

$123456 \quad 123$

$123456 \quad 123$

$123456 \quad 123$

$123456 \quad 123$

$123456 \quad 123$

$123456 \quad 123$

$123456 \quad 123$

$123456 \quad 123$

$123456 \quad 123$

$123456 \quad 123$

$123456 \quad 123$

$123456 \quad 123$

$123456 \quad 123$

$123456 \quad 123$

$123456 \quad 123$

$123456 \quad 123$

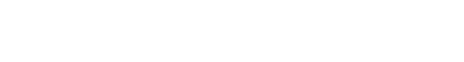
DN: $c \mathrm{c}=J$ John H. Hagen, $\mathrm{o}=$ West
Virginia University Libraries, ou=Acquisitions Department, 